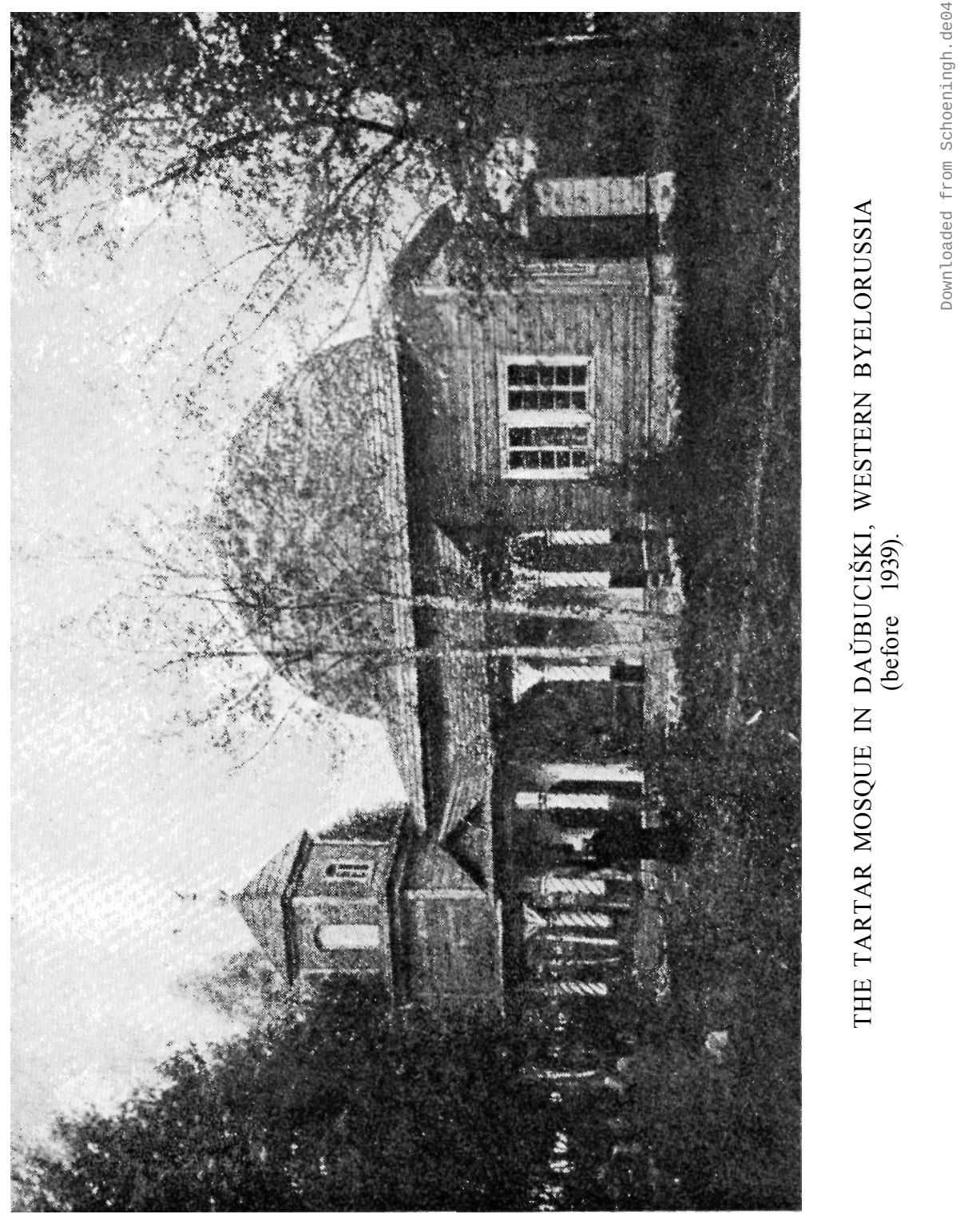




\title{
The Byelorussian Tartars and their Writings
}

\author{
BY \\ G. M. MEREDITH-OWENS and ALEXANDER NADSON
}

I

The Byelorussian Tartars today form a very small community numbering not more than 8,000 souls. ${ }^{1}$ They live in small, compact groups in various towns and villages in western Byelorussia. There are also nearly 2,000 Tartars in Poland, ${ }^{2}$ many of them completely polonised, and a few hundred in the Lithuanian Soviet Republic. This is all that remains of the once thriving Tartar settlements in Byelorussia, the beginnings of which go back to the 14th-16th centuries. The descendants of the early settlers have been long since integrated into the national life of the country, and speak Byelorussian, which they consider to be their native tongue. At the same time, mainly on account of their Moslem faith, they have retained down to the present day certain distinguishing features. Moreover, their writings in the Arabic script are an original contribution to the history of Byelorussian culture.

Byelorussia in the 14th-16th centuries formed part of the Grand Duchy of Lithuania. It was a multinational state in which the presentday Lithuanians and Byelorussians formed the two main ethnical groups. All the inhabitants of the Grand Duchy, irrespective of their ethnic origin, called themselves - and were called by others Lithuanians, while the official language was Byelorussian. ${ }^{3}$ It is for this reason that the Tartar settlers in Byelorussia were known as 'Lithuanian Tartars' until relatively recent times.

The name of 'Tartars' was originally given to those Mongol conquerors who, in the 13th century, invaded south-eastern Europe and imposed for over two centuries their dominion over what is today Russia and the eastern Ukraine. They established on the lower reaches of the Volga their state, known as the 'Golden Horde', which extended eastwards far into Asia, and in the south comprised the Caucasus and the Crimea. Soon afterwards the original Mongol invaders, who were comparatively few in number, were absorbed by the local populations of the region, who were mostly of Turkic origin. Already at the beginning of the 14th century a Turkic dialect had become the official language of the Golden Horde. The process of assimilation was speeded up by the conversion of the Tartars to the Moslem faith of the Sunnite persuasion. Soon practically all that remained of them was their name, which began to be applied to the entire population of the region, irrespective of their ethnic origin. ${ }^{4}$ In the 15 th century the Golden Horde began to break up into smaller political units, most of which were in their turn conquered in the 16th century by Moscow. 
Only the state of the Crimean Tartars managed to survive under the protection of Turkey until the end of the 18th century.

Byelorussia, unlike Russia and the Ukraine, was never under Tartar domination. It is true that the Tartars made several raids into Byelorussia, sometimes penetrating as far as Minsk, Słuck and Navahrudak, but they were always defeated and driven back. ${ }^{5}$ On the other hand the Grand Dukes of Lithuania made a practice of enlisting Tartar troops for their armies as early as the beginning of the 14th century. Thus in 1319 there were Tartar units fighting in the army of the Grand Duke Hiedymin (Giedyminas) during his struggle with the Teutonic Knights. ${ }^{6}$ They were also active in the armies of his successors, Alhierd and Kejstut. No doubt some of them settled permanently in the Grand Duchy. The real founder of the Tartar settlements in the Grand Duchy of Lithuania, however, was Vitaut (1392-1430). During his reign this state entered upon a period in which it achieved its greatest territorial expansion, with frontiers extending from the Baltic to the Black Sea. It thus came into direct contact with the Golden Horde. In 1394 the khān (king) of the Golden Horde, Tochtamyš, was deprived of his throne by Temür-Kutlug, the grandson of Tamerlane. He and his followers sought asylum in the Grand Duchy of Lithuania. Vitaut received him with honours, gave him the city of Lida for his residence, and promised to help him to regain his throne. In 1397 he organised a successful campaign, from which he returned with many captive Tartars. A second campaign in 1399 ended in disaster. Vitaut was defeated at the river Vorksla by Temür-Kutlug and was only able to save himself by speedy flight. It was the captives brought back from the first campaign who formed the nucleus of the Tartar settlements in Byelorussia. Vitaut granted them freedom and resettled them on grand-ducal lands by the river Vaka near Vilna, and also in the districts of Troki, Lida, Ašmiany, Navahrudak, Brest (Bieraście) as well as in Volhynia. The land thus received was for their perpetual use, but remained the property of the Grand Duke, and the Tartars had no right to sell it, or otherwise freely dispose of it. In return for these grants, they were obliged, at their own expense, to do military service whenever required. They were thus in a position of vassal-dependency with regard to the Grand Duke, and were to be known henceforth as tatary haspadarskija (the sovereign's Tartars). Their position did not in fact differ from that of many native noblemen, with whom the Tartars, as members of the military class, enjoyed equal rights. Moreover, they were guaranteed the freedom to practice their Moslem religion and, as there was a scarcity of Tartar women, were permitted to take Christian wives from among the local population. In such a marriage the wife remained Christian, but the children followed the religion of their father. The Tartars for their part renounced completely the practice of polygamy.

Soon the original settlers were joined by others, many of whom came of their own free will, attracted no doubt by the favourable conditions existing in the Grand Duchy. A particularly large number seems to have remained there after 1410, when a sizable contingent 
of Tartar soldiers, led by Tochtamyš's eldest son Dželal-ad-Din, fought under Vitaut at the battle of Grünwald, where the joint Polish-Lithuanian forces defeated the Teutonic Knights. ${ }^{8}$ On the whole the entire period of Vitaut's reign was distinguished by the cordiality of his relations with the Tartars. When towards the end of his life the Crimea broke away from the Golden Horde and became an independent state, it was the Tartar Hadžy-Devlet Girey, brought up and probably born in the Grand Duchy, who became its first khän, not without Vitaut's help. ${ }^{9}$ All his life he remained the most faithful and loyal friend of the Grand Duchy.

The benevolence shown by Vitaut towards the Tartars gained him their deep respect, and his name was venerated by them for many years after his death. Thus in 1519 the Tartars, in an address to the Grand Duke Sigismund, had this to say about Vitaut: "We have no longer Vitaut among us; he did not command us to forget the Prophet, and we, turning our eyes towards the Holy Places, repeated his name together with those of our Caliphs. ${ }^{10}$ And in 1558 the author of the report on the state of Lithuanian Tartars, known as Risāle-i Tâtār-i Leh, written at the command of the Grand Vizier Rüstem-Pasha, expressed himself thus: 'The name of this monarch, who was like a pillar of Islam in the land of unbelievers, is Vitaut, and the memory of him has been preserved to this day, for every year we celebrate a day dedicated exclusively to the memory of that king.'

Hadžy-Girey died in 1468 and was succeeded by his son MengliGirey, who obtained the throne with the help of Turkey after a struggle with other pretenders. His opponents and their followers fled the country, many of them settling in the Grand Duchy of Lithuania. ${ }^{12}$ Unlike his father, Mengli-Girey displayed a marked hostility towards the Grand Duchy, and in his reign that country was ravaged several times during the raids of the Crimean Tartars. One of the most vicious raids took place in 1506, when the Tartars penetrated as far as Kleck in central Byelorussia. There they were completely defeated by the armies of the Grand Duchy of Lithuania under the command of Michael Hlinski. Many prisoners taken in the battle were later resettled by Januš Radzivił, nicknamed 'The Bearded' - who during the battle commanded the artillery - on his estates in Minsk and Kleck. ${ }^{13}$ The descendants of those Tartars still live there to this day. The Tartar settlers in Byelorussia took an active part in the military actions against the Crimean Tartars. When in 1508 the latter rebuked them for fighting against their kinsmen, they received the following answer: 'Neither God nor the Prophet have ordered you to plunder and us to be ungrateful; we consider you to be bandits, and in defeating you with our swords, we slay not our brothers but robbers. Sit quietly beyond the Volga until others drive you out. We shall shed our blood for the Lithuanians near Vaka, who consider us to be their brothers. ${ }^{14}$ After the death of Mengli-Girey in 1508, the relations between the Grand Duchy of Lithuania and the Crimean Tartars improved again. 
In the 16th century the number of Tartars in the Grand Duchy of Lithuania was considerable, although the estimates vary widely from 40,000 to $200,000{ }^{15}$ The most important group was the military class, the Tartar noblemen - the kniazi, murzy and utany - who enjoyed rights equal to those of the native nobility. They were organised in their own regiments (ściahi) with their own officers (charunžy and maršatak) appointed for life by the Grand Duke. In 1569 the Grand Duchy of Lithuania and Poland, after nearly two centuries of a somewhat uneasy alliance, signed in the city of Lublin an act of union, forming thereby a single Commonwealth with one king and one parliament. Each country, however, retained its own chancery, treasury, army and code of laws. One of the consequences of the union was to make absolute the right of noblemen to the land they possessed. Thus several Tartars became landowners.

Not all Tartars were nobles. Many of them were simply farmers and burghers. Some of them settled on lands belonging to certain magnates and became their bondsmen. The chief occupations of those Tartars were farming, gardening (in which they excelled), tannery and furmanstva or the carrying of wares for various merchants. In this latter occupation they practically established a monopoly. It must have been a lucrative business, but not devoid of danger. Thus on 28 February 1593 at the county court in Minsk two furmany (cartdrivers), Jurka Achmetovič and Mikałaj Jakušovič, subjects of the tataryn haspadarski (sovereign's Tartar) Prince Ilja Łukaševič from the Vilna district, complained that 'on 26 February... being sent by our master with the wares of the burgher of Minsk Ivan Baburka to the said city of Minsk, and having consigned them intact to the said Baburka and being ready to return to Vilna... the burghers of Minsk Siamion Savič and Andrej Kakoŭka, having no business whatsoever with us and without any reason, having stopped us... took one of us, namely Jurka Achmetovič and put him, although innocent, into prison in chains at the Minsk Town Hall, where he was kept for a whole night and day and then released, his detention having caused not inconsiderable damage to our master. ${ }^{16}$ The Tartars, for their part, were not always the most law-abiding of citizens. On 14 March 1599 before the same court in Minsk the clerk of the old Minsk excise office, Vasil Maślanka, complained that 'the Minsk Tartars, subjects of the... Prince Christopher Radzivil, who live in this city of Minsk and who travel with merchandise for the purpose of gain to Słuck and Kapyl and other places, refuse to declare their wares at the toll-gate, thus causing not inconsiderable damage to the treasury of His Royal Majesty and my Master.'17

The great majority of Tartars in Byelorussia in the 16th century had already forgotten the language of their fathers and spoke Byelorussian. This process of abandoning their native tongue was no doubt accelerated by mixed marriages with Byelorussian women. The Tartar nobles, together with their Byelorussian counterparts, underwent a further process of polonisation, especially after 1569, when the Polish influence in the Grand Duchy of Lithuania began to make 
itself felt with particular intensity. ${ }^{18}$ Many Tartars formed their patronymic names in the Byelorussian manner by adding suffixes $-i c ̌$, or -ovič to the names of their fathers. So it is that one finds family names such as Asanovič, Achmatovič, Abdulič, Chasienovič, Murzič, Safjanovič and others. Others adopted patronymics like Aleksandrovič, Bahdanovič, Kalina, Navasielski, Sienkievič which in no way differed from Byelorussian names. For the most part, however, they retained Tartar (or rather Arabic) first names, the most popular male names being Abas, Ali, Abrahim, Achmet, Husein, Furs, Mustafa, Murtuz, Obrachman, and the female Ajša, Chava, Fatma, Chadzia, Selima and some others. The Tartars often lived in their own villages, some of which had names such as Sorak-Tatary, Arda, Afundzievičy, Tatarskaja Stabada which gave at once an indication as to the character of their inhabitants. In the towns they had their own quarters, generally called Tatarskaja vulica or Tatarski kaniec.

In all matters pertaining to their relations with other groups of population, the Tartars fell under the jurisdiction of the ordinary courts of the land. Among themselves they settled their differences according to Koranic law, but it seems that even in those cases they often preferred to submit to the ordinary courts. They appear to have been a rather turbulent community, and quarrels, fights and raids on neighbours' property were not infrequent among them. Thus on 28 April 1590 in the county court in Minsk the tataryn haspadarski (sovereign's Tartar) Milkuman Alejevič Starynak from the county of Minsk filed the following complaint against another tataryn haspadarski, Prince Chasien Bahdanovič: 'On 26 April I was proceeding along the free highway to my house in Starynki... and when I was nearing my home, Prince Chasien Bahdanovič, giving vent to his free will, came out of his house together with his hirelings and assistants and, having barred me from my passage on the free highway, outside my own gate, on my own land, for no reason whatsoever began to pull me by the hair on my forehead and to strike me with a stick, and when my wife Sałtana Skidyraŭna, having heard the affray, ran out to my assistance, the said Chasien, as if beating me was not enough, hit my wife Sałtana in the face with his fist, so that she began to bleed." 19 The most frequent incidents were the quarrels over property rights. On 12 October 1679 the magistrates' court in Troki heard the complaint of a Tartar, Tamaš Ejsič Tajrajevič and his wife Chadzia against the Tartar Chasien Achmatovič Šałkoŭski and his wife Ajša concerning 'the forcible occupation of the garden, which was the patrimonial property of the plaintiff Ejsič... and the appropriation of the profits therefrom every year beginning with the year $1667 \ldots$ and the forcible appropriation of the common pear tree growing on the border, and shaking (down the pears from) it without giving the plaintiff his rightful half, as well as the destruction of the fence around the garden. ${ }^{20}$ In all fairness it must be said, however, that the Tartars were no worse in this respect than the native inhabitants. 
Practically every larger settlement possessed a mosque, which was called mečyć, from the Arab mesdjid meaning the place of prostration. The author of the Risāle puts the number of mosques at over one hundred. They were usually modest wooden buildings, without any high minarets, from which the muezzins could summon the faithful to prayer. Instead, according to the author of the Risāle, the call was performed in the following manner: 'Azan (i. e. the call for prayer - A. N.) is made before the mosque. In some places there is a curious custom, namely that before prayer-time one of our people goes round the streets, calling everyone for prayer. Nowhere else have I seen such a custom... and I was assured unanimously, that it is contrary to the practice of the Prophet and therefore cannot be tolerated in the lands of the Believers. I reckon, however, that this is done in those parts to ensure that all people come eagerly to prayer and avoid being late, which may easily happen in non-Moslem countries, particularly in places where there is only one mosque and our people are scattered in various districts and the muezzin's voice cannot reach the more distant parts. ${ }^{21}$ According to the same source, the Byelorussian Tartars obtained their imāms (priests), whom they called mullās, from the Crimea or some other Tartar Horde. Near some of the mosques the mullās kept small schools for the religious instruction of the young.

In 1587 the Swedish-born Sigismund III Vasa became king of the Polish-Lithuanian Commonwealth. He was a fervent but narrowminded Catholic, and during his long reign (he died in 1630) the country had its share of religious intolerance, from which it had previously been free. The non-Christians fared worst. Already in the last edition of the Lithuanian Statute in 1588, Tartars were debarred from holding any public office, and were forbidden to keep Christian bondsmen and nurses. Other restrictions followed early in the 17th century. Marriages between Tartars and Christians were forbidden under the penalty of death for both parties. Tartars were also debarred from holding the rank of an officer in their own regiments, and they were forbidden to build and repair mosques, or acquire any freehold land. ${ }^{22}$ At the same time public opinion became hostile towards the Tartars. A certain Peter Czyżewski, whose father was killed in a drunken brawl by a Tartar Assan Alejevič, published in 1616 in Polish a book entitled Alfurkan tatarski, in which he accused the Tartars of all kinds of crimes and depravities. Tartar women, who liked to adorn themselves with all kinds of Oriental trinkets, were not infrequently suspected of witchcraft. Perhaps the greatest wrongs, however, were those done to the Tartars by the Polish noblemen. When in 1656 the Grand Duchy of Lithuania was invaded by the Swedes, many Tartars left with their families and their movable goods to find safety in Poland. After the Swedes penetrated into Poland, the Tartars decided to return home. It was then that they were attacked by bands of Polish nobles, avid for easy gain. The most flagrant incident occurred on Easter Thursday 1656, when a convoy of 300 horse-carts was attacked near Zambrów 
by the Poles, who killed and wounded the Tartars, assaulted their womenfolk and plundered their goods. ${ }^{23}$ It was during this period that many Tartars decided to emigrate to Turkey, whilst the others became Christians, and the Tartar population in Byelorussia was drastically reduced. There was some improvement in their position towards the end of the 17th century, but the right to build and repair mosques was not restored to them till 1768. It should be noted that all the restrictions and discriminatory laws principally affected the Tartar upper classes, but made little or no difference to an average Tartar, who enjoyed no particular privileges and whose way of life differed little from that of the ordinary Byelorussian.

Towards the end of the 18th century the Polish-Lithuanian Commonwealth was partitioned between Russia, Prussia and Austria and ceased to exist as a state. Byelorussia became part of the Russian empire. The Tartar population of Byelorussia at that time was small; according to statistical information gathered at the end of the 19th century, their total number was about $11,000{ }^{24}$ The greatest concentration of Tartars was in the Minsk region, followed by the regions of Vilna, Hrodna and Koŭna (Kaunas). Cities with substantial Tartar settlements included Minsk (over 1,300), Słonim (over 700), Navahrudak (500), then Vilna, Hrodna, Vidzy, Ašmiany, Dokšycy, Lachavičy, Kleck, Iŭje and others. In the middle of the 19th century there were 17 mosques served by 12 mullass, chosen from among the local Tartar population. ${ }^{25}$

The Russian government tended to favour the Tartars and employed them in the lower grades of local administration in preference to other groups of local population. This policy, however, failed to secure their loyalty to the Russian authorities. Although Tartars were usually honest and conscientious officials, their sympathies were on the side of the local population, and there was hardly an anti-Russian uprising in which they did not take part. The old Tartar nobility was by this time completely polonised in the cultural sense, and many of them played a prominent part in the Polish national movement. The ordinary Tartars on the other hand - the peasants and the burghers - identified themselves with the local Byelorussian population, whose language and way of life they adopted.

Špilevski in his Travels in Paleśsie and Byelorussia, published in 1853, gives the following description of the Tartars of Kleck: 'The men have adopted the dress of the Byelorussian burghers, i. e. they wear high jack-boots polished with tar, long grey coats and peaked caps. The women have retained their national costume: they wear bright many-coloured short blouses, preferably orange and yellow, with wide sleeves, cover their shoulders with long red shawls and adorn their necks with several strings of large beads with various coral and silver figures... in their ears they put large silver earrings; they tie over their heads many-coloured bright kerchiefs in the form of a turban, with big knots over the forehead and long ends hanging at the sides; on their feet they wear boots with red heels and metal tips. ${ }^{26}$ 
The few remaining characteristics which distinguished the Tartars from the rest of the population had their roots in the Moslem religion, and in Oriental tradition. In particular they practised a variety of medicinal magic which consisted of writing an appropriate Koranic verse, or a prayer, or a spell on a piece of paper, a slice of bread or some other material. The material was then burned and the patient incensed with the smoke; alternatively it could be carried about or eaten by the patient according to the prescription. This kind of medicine was considered to be very potent, not only by the Tartars, but also by non-Moslems. A Byelorussian writer of Jewish origin, Zmitrok Biadula (1886-1941), relates in his autobiographical novel In the Dreaming Forests how, as a small boy, he fell ill and his mother, after trying in vain all the known remedies (which included visits to the wise woman Eva, and to the charcoal burner Karpucha) decided to take him to the Tartar Muńka: 'After two hours' walk and rest we finally reach the Tartar's farmyard. Dogs, as big as wolves, attack us. A young man, black, as though covered with soot, chases the dogs away. We enter the rich clean house of the Tartar Muńka. He has black eyes, a grey beard and a red skull-cap on his shaven head. He wears a long striped coat of calico. Such an interesting appearance cannot fail to inspire confidence. I begin to believe that he will cure me. Mother tells Muńka all the particulars of my illness. He listens patiently and nods his head. In the meantime he cuts off a large slice of bread, covers it with a thin layer of butter, opens on the table a thick book in leather binding and turns the pages for a long time, his eyes looking for something attentively. Finally he extracts a needle from his coat and begins to trace out on the butter some signs from the book. At home I swallow the wisdom of the Tartar book Kitab. But even Kitab did not help.,

The folklore and customs of the Byelorussian Tartars - if one excepts their purely religious aspect - are generally identical to those of Byelorussian peasants. ${ }^{28}$ Džamil Aleksandrovič relates a few original stories and legends, the most popular of which is that of the local 'saint' Kuntuś. According to the story, Kuntuś was a cowhand on the farm of a rich Tartar peasant. He was so holy that he used to fly secretly to Mecca to pray. One day the rich Tartar decided to make the pilgrimage to Mecca. On arriving there, however, he found that he had not enough money left for his return journey. $\mathrm{He}$ confided his worry to a sheikh who took him to the chief mosque at the time of night prayer, and, showing him a man in a green coat sitting in the front row, told the Tartar to go and sit by him and take hold of his coat, so that the man might not go away after the prayer. The Tartar did as he was told and, to his surprise, discovered that the man in the green coat was none other than his cowhand Kuntuś. The latter told him to hold tight to his coat and to close his eyes, and in no time they were back at home. Before that, however, Kuntuś had made his master promise that he would not tell anybody of what happened. Unfortunately the Tartar failed to keep his word and, giving in to the nagging of his wife, told her everything. No sooner 
did he do so, than he remembered his promise, ran out to Kuntuś and found him dead. The tomb of Kuntuś, outside the town of Siniaŭka near Kleck, became a place of pilgrimage for Byelorussian Tartars. ${ }^{29}$

The most interesting and valuable part of the cultural heritage of the Byelorussian Tartars lies in their writings in the Byelorussian language but in Arabic script, of which more will be said presently.

Living for centuries in close contact with Byelorussians, speaking the same language and following the same way of life, the Tartars have become deeply rooted in Byelorussia which they have come to consider as their native land. In recent years they have made a valuable contribution to the national life of the country. Many of them have achieved distinction in the intellectual field, as for example Bekir Smolski, fellow of the Byelorussian Academy of Sciences and member of the Institute of Heat Exchange in Minsk; the orientalist Džamil Aleksandrovič who in the 1920's, among other things, carried out some valuable studies on the history of the Byelorussian Tartars; Matthew Kanapacki, the one-time editor of the Byelorussian weekly in Poland Niva and author of several articles - in Byelorussian and Polish - on the writings and folklore of the Byelorussian Tartars; and the Byelorussian writer and literary historian Stephen Aleksandrovič, a reader in Byelorussian literature at the University of Minsk, who in his autobiography (published in 1966) has this to say about his origin: 'My native town is Kapyl which has spread over picturesque hills among the green forests and fertile fields of the land of Słuck. I was born on 15 December 1921. My parents were Byelorussian Tartars. It may seem strange, but it is true. In Kapyl there lived from times immemorial a small group of the descendants of the Mongol tribes. Their houses were situated along two streets - Tartar and Castle street, near to the shallow Kamienka river by the high castle ruins (according to the tradition, they formed at one time the personal bodyguard of the Prince of Kapyl). In their physical appearance, the local Tartars have retained certain Oriental traits, and have preserved some of their customs and traditions, but they have long since forgotten their native tongue and now speak Byelorussian. The occupation of the majority of them was tanning; some were gardeners and other simply farmers. On the whole the Tartars of Kapyl lived very closely with the local population, and their everyday life hardly differed from that of the Byelorussians. 30

Thus one can say that, at the present day, the Byelorussian Tartars form an integral part of the Byelorussian national scene.

The literature of the Byelorussian Tartars is essentially religious and intimately connected with their Moslem faith. Several works are known today, all in manuscript form, written in neat Arabic 
characters and reading in the usual manner from right to left. The language of the great majority of these writings is Byelorussian. There are, however, several texts in Polish and - as might be expected - in Arabic and Turkish.

There are comparatively few original works among the writings of the Byelorussian Tartars, the majority of them being translations from a variety of Oriental sources. The writings may be divided into a number of groups. In the first place there is Tefsir, or the book of the Koran written in Arabic with an interlinear translation in the vernacular (the Arabic word TEFSİR usually means a Koranic commentary). Next comes the Tedžvid, which is a treatise on how to read the Koran. The Chamail is an informal manual of prayers and ritual containing in particular several prayers and spells thought to have magic or medicinal powers. Finally there is the Kitab (known also as Kiciab and Kiciob, from the Arabic word KITĀB meaning 'the book') which is the most interesting collection, incorporating the tenets of the Moslem religion, moral precepts, ritual prescriptions, legends, pious tales and apocrypha.

The oldest known Tartar manuscripts belong to the first half of the 17th century, but there is little doubt that the origins of their writings go back to the 16th century. The writing - or copying - of books has been going on almost to the present day. According to Muchlinski, in the middle of the 19th century there was in Minsk a group of Tartars who were fully proficient in the Arabic script and were engaged in copying the Koran and other works of a religious nature ${ }^{31}$ Kanapacki relates that in 1966 there still lived in Biełastok (Białystok, now in Poland) the last of the Tartar copyists, the former mullā of the Daubuciški mosque Lut Muchla. ${ }^{32}$ He even grew saffron required in the preparation of a special ink.

The first scholar to draw attention to the writings of the Byelorussian Tartars was the German orientalist H. O. Fleischer who in 1838 gave a description of a copy of the Chamail (now in the Leipzig University library). Being, however, unfamiliar with the Slavonic languages, he was only able to identify a few Polish texts. ${ }^{33}$ Nearly twenty years later, in 1857, A. Muchlinski published a few extracts from the writings of the Byelorussian Tartars in Byelorussian and in Polish. ${ }^{34}$ Nothing else appeared on this subject until after 1915, when the well-known Byelorussian ethnographer Ivan Łuckievič acquired from the mulla, S. Parłtarakievič, in the village of Sorak-Tatary a copy of the Kitab. This Kitab was to become one of the best known Tartar manuscripts, thanks to the efforts of the philologist Janka Stankievič who devoted a lifetime to its study. ${ }^{35}$ Unfortunately the system of transliteration used by Stankievič is not free from subjective elements, and he erroneously determines the date of the Kitab as being in the 16th century, whereas in fact, as Antonovič has conclusively established in his most recent work, it was written in the 18th century. ${ }^{36}$ Other authors who wrote in the 1920's and 30's on the writings of the Byelorussian Tartars include Ju. Kračkoŭski, J. Karski, J. Szynkiewicz, Chr. S. Stang. ${ }^{37}$ After the Second World War, 
FIG. 1. TABLE OF CONSONANT LETTERS USED BY THE BYELORUSSIAN TARTARS.

Independ- Final Medial Initial Equival- Transliterent ent ation
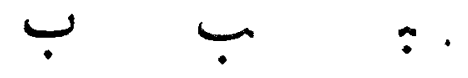

?

b

b

$\vartheta_{*}$

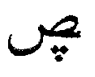

$\stackrel{0}{\bullet}$

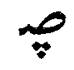

$C, C^{\prime}$

C

ट

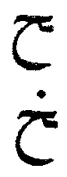

$x$

$>$

$\mathrm{ch}$

ch
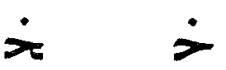

"

ch

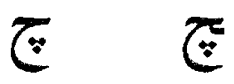

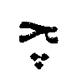

$\because$

Č

c

3

1

J

$d$

d

3

4

3

$d z^{\prime}$

$d z ́$

$\tau$

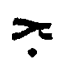

$?$

$d z$

$d z$

$\dot{2}$

$\dot{9}$

f

f

$\dot{\varepsilon} \dot{c}$

$\dot{3}$

$\bullet$

d

8

$\dot{c}$

9

9

$\infty$

h

h

$S$

$\therefore$

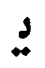

j

j

$\ddot{\theta}$

$\ddot{g}$

$\ddot{q}$

s)

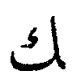

$\ddot{s}$

k

k

久

5

k

$k$

$\omega$

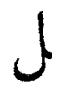

$\downarrow$

1

$1, I^{\prime}$

I

r

$\infty$

$\infty$

$\mathrm{m}$

$\mathrm{m}$

$\dot{ن} \dot{ن}$

:

$n, n$

$n$ 
Independ- Final Medial Initial Equival- Transliterent ent ation

\begin{tabular}{|c|c|c|c|c|}
\hline$\omega^{*}$ & $\Psi_{*}$ & $\tilde{\nabla}$ & 8 & $p$ \\
\hline$J$ & S & J & 3 & $r$ \\
\hline & & $a$ & $ص$ & $\mathbf{S}$ \\
\hline & & $\triangleq$ & $\dot{s}$ & $S^{\prime}$ \\
\hline $\mathcal{U}$ & $\mathcal{J}$ & سم & سـ & $n$ \\
\hline "ָ & w & 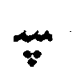 & ي & $"$ \\
\hline شُ & شن & شّ & ش & $\grave{\mathbf{S}}$ \\
\hline & b & $b$ & $b$ & $t$ \\
\hline ע & ت & $\ddot{z}$ & $\ddot{j}$ & $t, c^{\prime}$ \\
\hline 9 & 9 & 9 & 9 & $v, \check{u}$ \\
\hline$b$ & ظ & $\dot{b}$ & $\dot{b}$ & $\mathbf{z}$ \\
\hline & خ & $\dot{a}$ & ض & $"$ \\
\hline ; & j & j & j & $z^{\prime}$ \\
\hline j & $\dot{j}$ & $\dot{i}$ & $j$ & $"$ \\
\hline 3 & $\dot{\xi}$ & $\dot{\xi}$ & $\dot{j}$ & 之 \\
\hline & 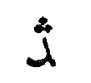 & $\dot{\jmath}$ & j & $"$ \\
\hline 1 & 1 & 1 & 1 & - \\
\hline & 2 & $\boldsymbol{x}$ & $\varepsilon$ & - \\
\hline
\end{tabular}


FIG. 2. VOWELS.

Final Initial Equivalent Transliteration
medial

\begin{tabular}{|c|c|c|c|}
\hline and medial & Initial & Equivalent & Transliteratior \\
\hline$\Gamma$ & 1 & a & a \\
\hline & 6 & $"$ & 'a \\
\hline & T & $"$ & ã \\
\hline$v=$ & & $"$ & â \\
\hline 1 & & $"$ & $a$ \\
\hline ا'ي ,'ائ & & $"$ & $\hat{a}$ \\
\hline$=$ & & $e, a$ & $e$ \\
\hline & $\varepsilon^{-}$ & $"$ & e \\
\hline 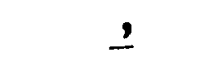 & i & 0,4 & $0, u$ \\
\hline$\dot{g}$ & أُوُ & " & $\hat{o}, \hat{u}$ \\
\hline & $\stackrel{2}{\varepsilon}$ & $"$ & 'o,u \\
\hline & مُو & " & 'ô, '̂u \\
\hline$g^{-}$ & g) & 0 & 0 \\
\hline & $\bar{g}$ & $"$ & 'o \\
\hline$=$ & -1 & $\mathrm{i}, \mathrm{y}$ & $\mathbf{i}$ \\
\hline$v=, s=$ & 少 & $"$ & $\hat{\imath}$ \\
\hline & $\underline{\varepsilon}$ & $"$ & i \\
\hline TS, & & $"$ & $\hat{\imath}$ \\
\hline ijg & & & a \\
\hline
\end{tabular}


FIG. 3. SPECIAL SIGNS.

\begin{tabular}{|c|c|c|}
\hline Sign & Name & Symbol \\
\hline 1 & Sukūn & - \\
\hline$\omega$ & Shadda & $\star$ \\
\hline$\sim$ & & $\sim$ \\
\hline- & Madda & \\
\hline$\varepsilon$ & Hamza & 1 \\
\hline 7 & Damma & - \\
\hline- & Fatha & - \\
\hline & Kesra & - \\
\hline
\end{tabular}

in 1952, the Polish orientalist A. Zajączkowski published a short study of a Chamail of 1814 discovered by him. ${ }^{38}$ During the last decade M. Kanapacki has published a few articles in Byelorussian and Polish in which he describes a number of Byelorussian Tartar manuscripts now in Poland, among them a Kitab of $1631 .^{39}$ Finally in 1968 there appeared in Vilna a book (in Russian) entitled The Byelorussian texts written in the Arabic script by A. Antonovič. ${ }^{40}$ It is a thorough and scholarly study of the graphico-orthographic system of the Byelorussian Tartar writings, based on a wealth of concrete material (the author examines and describes 24 manuscripts) and constitutes an indispensable guide for any future student of the subject.

The Arabic alphabet adapted by the Tartars for the Byelorussian language has 35 consonant letters (Cf. Fig. 1). ${ }^{41}$ Each letter has three different forms - initial, medial and final - depending on its position in the word, and the fourth form - independent - when it is written separately and not in conjunction with other letters. Certain letters seem to be superfluous. Thus there are two letters each to 
represent $\mathrm{CH}$ (transliterated as "ch" and "ch"), Z ("z", “ $z$ ”), Z' ("ź",

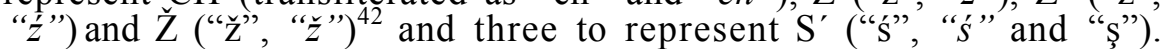
Four of these letters, however - "ch", "s", " $z$ " and " $z$ " - are rarelyused. The remaining two pairs - "s", "s" and "z", "z" - are used concurrently in most manuscripts, although individual writers usually show a preference for one letter of a given pair.

A special feature of Byelorussian texts written in Arabic characters is the distinction made between 'hard' consonants $\mathrm{D}, \mathrm{S}, \mathrm{T}, \mathrm{Z}$ and their 'soft' counterparts DZ' (transliterated as "dź"), ${ }^{43}$ ' ("s', "s's" and "s"),

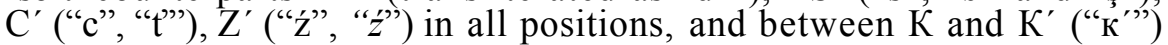
before vowels. In the conventional Middle and Modern Byelorussian orthography in the Cyrillic script the softness of these consonants is not indicated in a separate position or before another soft consonant. On the other hand, in the Tartar writings there is no way of distinguishing between L, N and L', $\mathrm{N}^{\prime}$ in all positions, and there is also no indication of hardness or softness of other consonants such as $\mathrm{B}, \mathrm{M}, \mathrm{P}, \mathrm{V}$ before vowels. This is one of the major shortcomings of the Arabic alphabet as applied to the Byelorussian language. Thus the word "laska" may mean grace (Cf. taska in the conventional Byelorussian Latin alphabet; ласка in Cyrillic) or stick (Cf. laska; ляска). Similarly the Byelorussian word for horse is written "kon" (Cf. koń; конь), and for meat - "masa" (Cf. miasa; мяса). In some cases the softness of these letters is indicated indirectly by the fact that they are preceded by a known soft consonant, such as $\dot{S}$ or $\dot{Z}$, e. g. "iź modu" (from honey), "śvet" (the world).

The letters "dź" and "c", introduced by the Tartars, enabled them to represent the characteristic features of the Byelorussian language known as dziekańnie and ciekańnie, in which the soft counterparts of $\mathrm{D}$ and $\mathrm{T}$ are respectively $\mathrm{DZ}^{\prime}$ and $\mathrm{C}^{\prime}$, and not the palatalised $\mathrm{D}^{\prime}$ and $\mathrm{T}^{\prime}$, as is the case, for example, in Russian. The letter "c" is somewhat ambiguous as it is also used to represent hard $\mathrm{C}$ which has no soft counterpart. However, the distinction between the two presents no difficulty in Byelorussian. Another letter for $\mathrm{C}^{\prime}$ is " $\mathrm{t}$ " which is also used to represent T. The letter "dź" is used to represent the sound DZ in words of Polish origin, e. g. "cudźoložnik'i" (adulterers).

The letter " $v$ " is used to represent $V$, as well as the $\breve{U}$ of various derivations (from V, U and L). In particular it is used in the past tense masculine singular endings of verbs instead of the etymological L, e. g. "živ" (lived), "činiv" (did). This is in keeping with conventional Middle Byelorussian usage, the letter "ŭ" being of comparatively recent origin.

Unlike conventional Byelorussian writings in the Cyrillic script, there is a strict distinction between " $h$ " and "g", the latter being written only in words of foreign origin. Another letter which occurs in foreign words only is " $\mathrm{f}$ ".

The two last letters in the table of consonants are called alif and 'ain and have no sound value. Alif is sometimes written after a final " $\mathrm{v}$ " and "l", probably to indicate the end of the word. 
The Arabic alphabet has only three vowels, namely A, U and I. They are formed by means of signs fatha, damma and kesra (Cf. Fig. 3) with or without one of the consonants alif, "v" (called wāw) and " $\mathrm{j}$ " (called $y \bar{a}$ ). In the first case long vowels are obtained, in the second - short. The Byelorussian Tartars have retained the division of vowels into long and short - the first being indicated in the present system of transliteration by a circumflex accent $\left(^{\wedge}\right)-$ but it had no effect on pronunciation. It happens not infrequently that a vowel in the same word is written as long in some cases, and as short in others.

Generally speaking, in the field of vowels the Byelorussian Tartars have shown much inventiveness (Cf. Fig. 2). They used alif with fatha (the Arabic long A) as the basic symbol for A, and fatha alone (the Arabic short A) for E. Not infrequently, however, the fatha alone is used to represent A in non-stressed syllables.

Initially the letters damma alone (short) and wāw with damma (long) were used to represent both $O$ and $U$. Since the distinction between these two vowels in the Byelorussian language is quite clear, the letters in question can be transcribed as "o" or as "u", as the case may be, without any danger of ambiguity. Towards the end of the 18th century, however, the Tartars themselves made an important improvement by introducing a special letter - wa w with fatha - to represent $\mathrm{O}$, leaving the former symbol for $\mathrm{U}$ only.

The letters kesra alone (short) and y $\bar{a}$ with kesra (long) represent both I and Y. Thus the word "biv" may mean 'he was' (Cf. Byelorussian conventional Latin spelling byü; Cyrillic бbiy) or 'he beat' (Cf. biü; бiy̆). This is another major shortcoming of the Arabic alphabet when applied to the Byelorussian language. In some cases the indication of the proper pronunciation of the vowel is given by the preceding consonant. Thus in the word "sila" (strength) the first consonant is soft and the following vowel must be pronounced as I, while in the word "sin" (son) the vowel follows a hard consonant and must be pronounced as $\mathrm{Y}$.

The last letter in the table of vowels is the Polish "a". It consists of the letter "o" (in any of the three possible forms) followed by " $\mathrm{k}$ '" surmounted by one dot, or, according to Antonovič, by three dots (the Turkish letter saghir nün). ${ }^{44}$ It is used in the final position in some Polish texts.

There is usually a difference between the initial and final forms of vowels. The medial form is usually identical with final, and independent with the initial. Strictly speaking, 'initial' is not the proper word when applied to vowels, because according to the Arabic orthography every syllable must begin with a consonant. This is why vowels at the beginning of a word are always preceded either by an alif or by an 'ain, which have no effect on pronunciation. For the same reason alif or 'ain are written in the middle of a word between two consecutive vowels, e. g. "na'uka" (learning). One should notice the special initial form of A, consisting of alif surmounted by a wavy line called madda ("ã"). It is used quite frequently in certain 
manuscripts. On the other hand final (and medial) forms of " $a$ ", " $\hat{a}$ " and " $\hat{l}$ " are comparatively rare. This profusion of vowel forms is naturally somewhat confusing. ${ }^{45}$

Of the special signs used by the Byelorussian Tartars (Cf. Fig. 3) the fatha, damma and kesra as well as madda have already been mentioned. The remaining signs are sukūn, in a form of a circle (which often degenerates into a semi-circle with its convex side pointing to the left) written over a consonant to indicate that it is not followed by a vowel; shadda (often written to look like madda) which indicates the doubling of the consonant over which it is written; and finally the glottal stop, hamza, which is very seldom encountered and then almost invariably in Arabic words.

Among the features of the Byelorussian language encountered in the Tartar manuscripts and not already mentioned, one notes in the first place akańnie, i. e. the writing and pronouncing of A in the place of the etymological unstressed O, e. g. "halava" instead of "holova" (head). In most cases the akańnie is of the so-called incomplete nondissimilative (or strong) variety, with the retention of $O$ in final open syllables, e. g. "dobraho" instead of "dobraha" (genitive singular of "dobry" - good). It is characteristic of the Byelorussian dialects of the south-western region, roughly below the line Lida-KapylSłuck, where there were several important Tartar centres (Hrodna, Słonim, Navahrudak, Lachavičy, Kleck etc.) Examples of the full non-dissimilative akańnie are also abundant.

Another feature characteristic of the Byelorussian language is the ending "-cca" in the infinitive and third person singular and plural present and future perfect of the reflexive verbs, the double $\mathrm{C}$ being usually indicated by shadda, e. g. "Molic*a" (he prays; cf. conventional molicса; моліица), "upjec*a" (he will get drunk; cf. upjecca; yn'euna).

A characteristic which is not evident in the Middle and Modern Byelorussian orthography, but which clearly appears in the Tartar writings, is the combination "ji" in words like "jich" (them; cf. conventional ich; ix), "majim", "majich" (dat. and acc. plur. of the pronoun "moj" - my; cf. maim, maich; мaiм, мaix).

Among the more curious traits one should mention the ending "-ij" in place of the more usual " $\mathrm{i}$ " in the nominative singular case of masculine adjectives, e. g. "śvetij" (saint), "starij" (old). This may reflect the influence of the conventional Middle Byelorussian orthography.

The language of the Byelorussian Tartar manuscripts is very closely related to the ordinary spoken language of the people, and reflects many features of the dialects of the south-western and central regions of the country. One of these features, the incomplete non-dissimilative akannie, has already been mentioned. Another feature is the ending in a "consonant $+\mathrm{je}$ ", or "consonant $+\mathrm{e}$ ", of certain neuter nouns in place of "double (soft) consonant $+\mathrm{e}$ ", which is the usual form in other parts of Byelorussia and is the accepted norm in modern literary Byelorussian, ${ }^{47}$ e. g. "bahamolje" (piety; cf. 
modern literary bahamolle; багамолле), "kerenje" (roots; cf. kareńnie; карэнне), "pitane" (question; cf. pytańnie; пытанне). A full study of the dialectal features of the Tartar manuscripts is beyond the scope of this article.

Only a few points concerning the Polish texts need be mentioned here. One relates to the letter "a", to which reference has already been made. It is used in the final position in some - but not all Polish texts. The Polish "rz" is almost invariably written as " $r$ ", and the ending of the masculine adjectives in the nominative singular is in most cases "-ij", which in the Polish language looks even more incongruous than in Byelorussian.

It will be evident from this short account that the Byelorussian texts written in Arabic characters, despite certain deficiencies, reveal numerous distinctive features of the Byelorussian language which are not always apparent in contemporary conventional writings. They therefore present considerable interest for the student of the Byelorussian language and its dialects. ${ }^{48}$

Apart from the Leipzig Chamail discovered by Fleischer in 1838, all known copies of the writings of the Byelorussian Tartars are either in the Soviet Union or in Poland, and nothing was known of them until recently in the West. It was only in 1969 that the authors of this article had the good fortune to come across three manuscripts in London. One of them is a copy of Tefsir, or the Koran in Arabic with an interlinear translation in Polish. It is a large book, measuring $31 \times 19 \mathrm{~cm}$. and containing 492 numbered folios (983 pages), in a leather binding with metal studs and clasps - the latter being rather an unusual feature in Moslem books. A Polish inscription in Latin characters at the bottom of the penultimate page gives the date of writing of the book as 1725. The colophon in the Arabic characters on the same page is very faded, but it is possible to read the name of the copyist, one Bohdan ibn Sevban Asanovič. It is known that a noble Tartar family with the name of Asanovič lived in the district of Minsk. The manuscript is written in a clear hand in yellowishbrown ink (probably made with saffron) interspersed with lines and words in red. The First Süra is surrounded with a frame and embellished with a flowery ornament in red, black and brown. Under each horizontal line of Arabic text there is a Polish translation, aligned obliquely to the original. The notes in the margins serve as an indication of the main argument of the text. Some notes are in a different hand and are obviously of later date. The translation is not literal and looks more like a paraphrase. The Polish language used in the translation is not free from Byelorussian elements, both in vocabulary and in the spelling. Apart from the text of the Koran, the book contains a few introductory chapters, one of which is a 
treatise on how to prepare for the reading of the Koran. The explanatory part of the treatise is in Byelorussian, but all the prayers are in Arabic or in Turkish. ${ }^{49}$ There is a similar chapter, containing the prayer to be recited after the reading of the Koran, on the last page of the book. The main orthographical features of the manuscript include a common symbol (damma and wāw with damma) to designate both $\mathrm{O}$ and $\mathrm{U}$, an almost exclusive use of " $z$ " and the initial "ă", and the frequent occurrence of the final "a". The letter "s" is also occasionally used. The Tefsir forms part of the collection of the Francis Skaryna Byelorussian Library in London.

The second manuscript, which belongs to the British Museum (numbered OR. 13,054), is a copy of a Chamail. ${ }^{50}$ It is a small book, measuring $17 \times 10 \mathrm{~cm}$. and containing 240 folios. As can be seen from the colophon on f. 228 v., it was written by Mustafa Bahdanovič in the city of Słonim in the year 1828. The last five folios are written in a different hand, and are presumably of a later date. Essentially the book is a collection of unofficial prayers, spells and pious intentions in Arabic and Turkish, with explanations in Byelorussian and Polish. The prayers, when recited or written on a piece of paper and worn as an amulet, were reputed to have the power of curing illness or protecting a person from all kinds of misfortune. Thus the devotees of one prayer are promised the following benefits: 'Whosoever recites this prayer or carries it on his person, to him the Lord God will give the salvation of the Four Prophets: firstly the salvation of the Prophet Muhammad; secondly that of Abraham; thirdly that of Moses; fourthly that of Jesus. Moreover the Lord God will give him the salvation of four angels: firstly of Gabriel; secondly of Michael; thirdly of Israfil; fourthly of Ezrail. So great is the salvation for those who chant or carry with them this prayer. Neither sword, nor arrow, nor any weapon will touch that man' (f. $142 \mathrm{v}$.). In the preface to another prayer it is promised that 'whosoever shall chant this prayer or carry it with him, then if he had as many enemies... as there are men and things in the world, they will do him no harm' (f. 150 r.). Certain prayers are endowed with the special authority of a tradition supposedly going back to Muhammad himself, as in the following instance: 'The most gracious Prophet said: Whosoever shall chant or carry with him this prayer, him will the Lord God protect from all misfortunes, from blindness and poverty, and at the moment of death he will pass away from this world with his faith intact, and the Lord God will preserve him from the snares of the devil' (f. $145 \mathrm{v}$.). Some prayers and spells are of immediate practical use, such as the one which is prefaced as follows: 'If a thief steals something, having written (the following), place it in water and give it to drink: the person who stole will be choked with this water' (f. 192 r.). Among medical texts some are of a diagnostic nature: 'If you require to know concerning a sick man, whether he will live or die, you may learn in this way: having written this talsim (i. e. amulet formula $T r$.) on a piece of paper, place it in water; if it comes to the edge, the patient will recover presently; if it circles in the middle, then he will 
be ill for a long time; but if it sinks, then he will die' (f. 191 r.). The following 'medical prescriptions' — among many others of this kind - are also recorded: 'For malaria: having written (the prayer) on three apples, eat them for three days' (f. 189 r.); 'For a pain in the chest: having written down (the prayer), place it in water, and give the patient to drink of this water' (f. 190 r.); 'For a fever: having written down (the prayer) on a piece of birch-bark, incense (the patient)' (f. 235 v.). Certain prayers and spells were to be written on a slice of bread - or even on a clove of garlic - and eaten (cf. f. 188 r.). Other 'prescriptions' were also possible. ${ }^{51}$ Apart from the chapters dealing with prayers and spells, the book also deals with various other actions, such as cutting one's finger nails, going to the bath house or making a new dress. Thus, according to one of the treatises, 'it is not good for a man to cut his nails on Sunday: such a man will lose his riches; it is good for a man to cut his nails on Monday: foolishness wi]l depart from such a man and he will gain in wisdom' (f. 201 r. et seq.). Occasionally one also finds quaint sayings which are typically Oriental in style: "An old man without learning is like a horse without a bridle... A learned man without good deeds is like a devil, a poor man without patience is like a dog, a rich man without goodness is like a pig' (f. 201 v.). Not all texts in the manuscript, however, are of this character. There are also a number of genuine prayers and pious intentions (nijet') for the living and the dead, and for every occasion. In particular there are intentions for those who died without leaving children, and thus presumably have no one to pray for them (ff. $21 \mathrm{v}$. $-22 \mathrm{r}$.). Other prayers aim at sanctifying a man's everyday actions. Thus there are prayers or intentions on waking up (f. 60 v.), after a meal (f. 37 v.), before starting a journey (f. 122 r.), on mounting a horse (f. 60 r.) etc.

Generally speaking, the number of Byelorussian and Polish texts is comparatively small, since the greater part of the book is composed of prayers and spells in the Arabic and Turkish languages. From the orthographical point of view the Chamail is of considerable interest in that there is hardly a letter-form (with the possible exceptions of "ch" and "ş") which is not used by the writer. The vowels O and U are represented by separate symbols, and the letters " $z$ ", " $z$ " and " $z$ " as well as the initial "ã" are generally used in preference to their respective alternative forms. The letter " $t$ " is used alongside the more usual "c" to denote C', as, for example, in the word "daśf" (he will give; cf. f. 143 r.). A special feature is the frequent occurrence of the letter-forms " $\hat{a}$ " and " $i$ ", and occasionally " $a$ ".

The third manuscript, also in the British Museum (numbered OR. 13,020), is a Kitab. This book measures $30 \times 19 \mathrm{~cm}$. and contains 125 folios, which have been recently numbered consecutively in pencil. At least one leaf is missing after both folio 5 and folio 96, as are all the leaves after folio 125. There is no indication as to the date when the manuscript was written. The watermark on the paper is a twoheaded eagle. Its exact parallel is not found in any of the current catalogues of watermarks which have been consulted, but closely 
resembles other watermarks on paper widely used in Byelorussia in the 18th century. The writer also uses separate symbols for $\mathrm{O}$ and $\mathrm{U}$. One can therefore tentatively assume that the book was written at the end of the 18th or the beginning of the 19th century. The language of the Kitab is Byelorussian and displays characteristics of the south-western dialects. There are a few Turkish texts with interlinear (or consecutive) translations into Byelorussian, and Arabic is used mainly in the Koranic quotations. These are always indicated by a line drawn over them, and followed by a translation. Strictly speaking there are no Polish texts, but some twenty pages are written in a mixture of Polish and Byelorussian. This is true even of the treatise on propitious and impropitious days, supposedly translated directly from Turkish into Polish (f. 121 r.). Numerous notes in the margins serve as titles to various chapters, and summarise the main trend of the argument. The whole book was evidently compiled by the same person.

The contents of the Kitab are rich and varied. It begins with genealogical tables, tracing the origin of various leading Moslem personages back to Adam (f. $1 \mathrm{r}$. et seq.). Then follow chapters on the Sūra Yā-Sin (Sūra 36), one of the most popular sūras of the Koran, used as a prayer for the departed (f. 6 r. et seq.). Several chapters deal with eschatological problems, which play an important role in Moslem theology. The titles of a few of these chapters give some indication of the range of subjects: About the mysterious world (f. $15 \mathrm{v}$.); The sun and moon will not rise for three days before the day of judgment (f. 16 v.); On the gate of penance (f. 17 r.); On the delights of Paradise (f. 22 r.); How hot is hell-fire (f. 24 v.); Death is the Moslem's delight (f. 50 r.); Every man desires to go to Paradise (f. $50 \mathrm{v}$.). Another substantial section is concerned with prayer, the reading of the Koran and the ritual duties of the Moslem, such as ablutions and fasting. These problems are dealt with in the chapters: Every prayer is a conversation with God (f. 31 v.); On those who chant the Koran (ibid.); God ordered Moses to observe the fast of Ramadān (f. 44 v.); On those who talk in the mosque (f. 48 r.); On guśel (i. e. the complete ablution - Tr.; f. 70 r.); On prayer (f. 78 v.) etc. The chapter On the things appertaining to the Moslem faith gives the following summary of the principal points every pious Moslem should know and observe: 'Firstly he must know One God; secondly he must make ritual ablutions; thirdly he must pray five times a day; fourthly he must observe the fast of Ramadān; fifthly he must give the alms-tax; sixthly he must make a pilgrimage to Mecca' (f. 57 r.). ${ }^{52}$ There is also a description and enumeration of God's strict commands (ferz) and counsels (vadžib), together with various salutary practices sanctioned on account of their observance by Muhammad, either frequently (sunnej) or occasionally (muste$d \check{z} e b$ ) (f. $69 \mathrm{r}$. et seq.). This is followed by an enumeration of things forbidden under the penalty of eternal damnation (cheram) and things which are not forbidden but are objectionable (mekruh) (f. 69 v. et. seq.). 
The chapter How one should live in wedlock contains the following forthright injunction: 'If a wife did as many good deeds as (there are things in) heaven and earth, but did not please her husband and was quarrelsome, then such a wife is cursed by God, by the angels and by all men' (f. 62 v.). The full rigour of this text is somewhat attenuated by the praise of conjugal love: 'If a man looks with love on his wife, then the Lord God will give him twenty salvations... If the man kisses his wife with love, then the Lord God will give him thirty salvations' (f. 63 r.). Conjugal infidelity is condemned in no uncertain terms, with an interesting reference to Mt. 5, 28: 'It is a poison and the devil's arrow to look at other men's wives, as Jesus the Prophet said: Look not upon other men's wives, that you may not desire; and if you have desired, then you have already committed adultery, not you but your heart. And the adulterers will arise on the day of judgment in the form of a dog' (ibid.).

Abstinence from alcoholic drink in a country where temperance is hardly one of the national virtues, evidently presented the pious Moslem with serious problems. This may explain a large number of texts condemning drink and drunkenness. Usually the consumption of alcoholic beverages is condemned as cheram, an invention of the devil, against which the Believer must be on his guard if he wishes to avoid hell. One Turkish-Byelorussian text begins thus: "He who, being drunk, shouts "hey, hey", in the next world in hell will cry "ow, ow", (f. 111 v.). In another chapter the following words are ascribed to Mas'ūd (probably one of the Companions of the Prophet): "When a man dies drunk, then bury him and at his head plant a tree; then open the grave again, and if his head has not become that of a pig and his face turned away from the south, then you can hang me on that same tree' (f. 118 r.). In the end, however, the Tartars seem to have arrived at a compromise: 'If a man, being thirsty, has a drink or two, especially of the beverage made of wheat, barley or millet, and does not get drunk, then it is not cheram but only mekruh, but if he gets drunk, then it is cheram. But if he goes to a tavern to enjoy himself, then even if he does not get drunk, or had just one drink, or did not drink at all, even so it will be cheram' (f. 66 v.).

Quite understandably the Tartars thought the Moslem religion to be best of all, but nothing could be worse than an unjust man: 'The Moslem says: God be praised for creating me a Moslem and not a Jew; the Jew says: God be praised for creating me a Jew and not an Unbeliever; the Unbeliever says: God be praised for creating me an Unbeliever and not a dog; the dog says: God be praised for creating me a dog and not a pig; the pig says: God be praised for creating me a pig and not an evil man' (f. 117 r.).

The most interesting parts of the manuscript are the numerous stories, legends, apocrypha and anecdotes from various Oriental sources. The longest story is the Me'radž (MI'RĀDJ, meaning originally 'ladder', or 'ascent'), or account of the ascension of Muhammad to heaven and his heavenly visions, written in Turkish 
with interlinear Byelorussian translation (f. $86 \mathrm{v}$. et seq.). It is a very well-known legend, popular in the Moslem world and existing in several literary versions. In its final section the text contains the following passage: 'Abu Bek'ir Chadži Muchammed said: those who believe in this Me'radž will wear the selevet' crown' (f. 102 v.). The reference is probably to Abū Bakr Muhammad b. Khair (d. 1197) who may have been the author of this particular version. Other stories in the Muhammad cycle include Muhammad's conversation with the Devil (f. 63 v.), the death of Muhammad (f. 107 v.), and the description of Muhammad's physical appearance (f. 120 r.), the latter text being in the Turkish language with an interlinear translation into a mixture of Polish and Byelorussian.

Another interesting long story, written in the same variety of mixed language, is the Story of the Prophet Jesus (f. 11 r. et seq.). This might more properly be called the story of Chebib Nedždžar (HABĪB AL-NADJDJAR, or 'Habib the carpenter'), an inhabitant of Antioch converted to the true faith by the two disciples of Jesus, Jahja and Ševban (whom the Tartar writer in a marginal note calls by the more familiar names of John and Stephen) sent by him to that city. In their zeal they gave offence to the king of Antioch, who imprisoned them. Jesus then sent another disciple, Seme'un (the writer notes in the margin that Seme'un is Peter). But he, too, failed, and all three of them faced death at the hands of an incensed mob. When Chebib Nedždžar heard of this, he came to the city (after his conversion he retired from the world and lived the life of a hermit) and tried to save the lives of the disciples, but was given the choice either of renouncing his faith, or of being put to death together with them. Chebib refused to renounce his faith and, after many tortures, was put to death. But, 'in the hour of death, as during his life, he did not abandon his teaching. Those people persecuted him, and he prayed for them to God, for, being a friend of God, he did not seek revenge' (f. 13 r.). The whole story is based directly on the Koranic passage of Süra 36, 11-26, in which no mention is made of any names. Its origins, however, go back much further, probably to Christian sources, and it is usual to identify Chebib Nedždžar with the prophet Agabus of Acts 11, 28 and 21, 10.

At the beginning of the apocryphal story of the death of Mary there occurs the following passage: 'Veheb, son of Munebeh, may the grace of God be upon him, said: This is what I have found, seen and read in other books' (f. 85 r.). The early Arab writer of Persian origin Wahb b. Munnabih (d. 728) was considered by his contemporaries to be an authority on Christian and Jewish traditions, but this is certainly not evident from the story.

Apart from these lengthier tales, there are a number of shorter ones, many of which make delightful reading. A few examples of these are given in the Appendix.

A curious 'medical' treatise is worth mentioning. It begins with these words: 'Man has a soul and blood; the members of the human body are thresholds. The human soul is like a moon. The moon in 
the course of four weeks crosses all (heavenly) thresholds and wherever it comes, shines forth. In the same manner the human soul wanders through all members (of the body), being each day in a different member. On the first day of the month the soul is in the feet, in the sole of the big toe. One has to guard that spot, lest it be hurt. Whosoever falls ill on the first day, will be ill for three days, and if he does not get well, he will not recover for one month. On the second day the soul dwells in the calves of the legs; whosoever shall fall ill on that day, will recover after four days' (f. 112 v.). The treatise continues in this vein until all days of the month and all members of the human body have been exhausted.

The last chapter of the Kitab, the end of which is missing, is a collection of moral and religious precepts arranged in accordance with the order of letters of the Arabic alphabet. It begins thus: 'There are twenty-nine letters in the alphabet, each letter by the will of God exhorting man and teaching him. Alij says: Hey, man, remember the estate to which you were born, know the Lord God and the Divine commandments, worship the Lord God; having known the Lord God, serve Him. $B a$ says: Remember, man, what to expect from the Lord God if you will not observe the Divine commandments; you must learn the Divine commandments and fulfill them, you must respect your father, mother and your relations' (f. $124 \mathrm{v}$.). The whole treatise is reminiscent of various pious Azbuki, or 'alphabets' (Azbuka pokajannaja, azbuka tołkovaja etc.) which were popular in Byelorussia during the 16th-17th centuries and which one finds in various primers and grammars published at that time.

Apart from the separate symbols for $\mathrm{O}$ and $\mathrm{U}$, of which mention has been made, other graphic features of the manuscript include consistent use of the letter " $\mathrm{z}$ " and the recurrence of "ain with initial vowels. Initial "ã" is used very seldom.

This description is not intended to be exhaustive, but it shows that a detailed study of the Byelorussian Tartar manuscripts may be of considerable interest and prove to be extremely rewarding.

\section{NOTES}

1. Reflc Muzafaraŭ, 'Pra biełaruskioh tatar', Polymia, Minsk, 1966, p. 151.

2. M. Konopacki, 'O muzułmanach polskieh', Przeglad orientalistyczny, 3, Warsaw, 1962, p. 238.

3. Unless otherwise stated, the names Lithuania, Lithuanian etc. in ithis article are used in their historical meaning to denote the Grand Duchy of Lithuania and 'its inhabitants.

4. The Byelorussian Tartars themselves were not particularly happy at being called Tartars, as appears from the work known as Risāle-i Tatär-i Leh, written in 1558: 'We are called in these lands by the general name of Tartars, although it seems that the majority of us are not descendants of those barbarians who have always been held by the Moslems in the greatest contempt, but rather of the noble and brave nation of the Seldjuks, ancestors of the present-day Ottomans. We do not lead a nomadic life, living under tents and wandering from place to place. But in these countries it is all the same: whosoever professes a faith different from that of the 
unbelievers is called Tartar' (Cf. A. Muchlinski, 'Zdanie sprawy o Tatarach litewskich, przez jednego z tych Tatarów złožone sułtanowi Sulejmanowi w r. 1558', Teka wileńska, 4, Vilna, 1858, pp. 253-54).

Risāle-i Tâtār-i Leh is a report on the state of the Tartars in the Grand Duchy of Lithuania, written in Turkish in 1558 at the command of the Grand Vizier Rüstem-pasha, the son-in-law of the Sultan Süleimān. The author was a Lithuanian Tartar who stopped in Constantinople on his way to Mecca. The report was translated into Polish and published in the Teka wileńska in 1858 by $\mathrm{A}$. Muchlinski, a native of Byelorussia and a professor of Turkish at St Petersburg University.

5. The Lithuanians themselves were conscious of their military superiority over the Tartars. Michael Tyškievič, who in about 1550 , under the pseudonym of Michalon Lithuanus, wrote a book entitled On the Customs of Tartars, Lithuanians and Muscovites, has this to say on the subject: 'Quando tamen praeter technas et stratagemata, sed recta et cominus, collatis signis, venit conferenda eis manus, praevalent tunc in eos pugnatores nostri, etiam si non paulo pauciores fuerint' (Michalonis Lithuani De moribus Tartarorum, Lithuanorum et Moscorum, fragmina X, Basle, 1615, p. 6).

6. A description of the battle order is found in Koialowicz: 'Gediminus vero ita aciem instruxit, ut Russorum cohortes parte latera, parte extremam aciem firmarent; Lituani in medio constiterent; Tartari frontem occuparent' (A. W. Koialowicz, S. J., Historiae Lituaniae pars prior, Gdansk, 1650, p. 248).

7. Koialowicz gives the following account of the first Tartar settlers: 'Captivorum integrae tribus (Hordas illi vocant) cum imbelli sexu atque aetate abductae sunt. Pars illorum ad Iagellonem Regem missa, deserto impio Mahomete, ad Christiana sacra, in Polonia transiit. Qui vero in Lituania sedes acceperunt, obstinatissime suam sectam retinent: non solum ad Vacae amnis ripas, sed etiam tum per agros, tum per suburbana regiarum civitatum, primorumque Lituaniae sparsi. K nobilitate fere Scytica originem ducunt, qui a Magnis Lituaniae ducibus attributos agros possident, et per suae gentis tribunos ac signiferos cento numere, propriis impensiis militare debent' (Op. cit., pars altera, Antwerp, 1969, pp. 59-60).

8. The Tartars did not like to be reminded that their forefathers who first settled in the Grand Duchy were prisoners of war, and claimed that they came there of their own free will to help the Lithuanians in their fight against the Teutonic Knights. One of their original legends, recorded by Džemil Aleksandrovič, runs as follows: 'The Teutonic Knights attacked the Lithuanians and, as they were sorcerers, the Lithuanian weapons could not harm them. Then the Grand Dukes of Lithuania appealed to the Tartars for help. The Tartars brought such terror upon the Germans, that among the latter a firm belief grew up that "the Turks are impervious to bullets"”, (Džemil Aleksandrovič, 'Litovskije tatary', Izvestija Obščestva obsledovanija $i$ izučenija Azarbejdžana, 2, Baku, 1926, p. 94).

9. Michalon Lithuanus has this to say on the subject: 'Et sensim deinde invalescens ibi illa Tartarorum vis, ad iustumque populi examen propagata, protulit sibi principem Temirkuthla quendam sanguinis sui, appelato eo Caesare. At progenitores S. Majestatis Vestrae (i. e. Sigismund Augustus, Grand Duke of Lithuania and King of Poland, to whom Michalon dedicates his work), perdomitis Caesarianis illis, iniquis Graecorum vasallis, dabant eis in Caesares subditos suos, hinc ex Lithuania Tartaros. Ultimus vero ex Lithuania Oaesarum Aczkirei, hic apud Troki natus, et hinc a divo Withovdo ad imperium illum missus, genuit ibi in Taurica filium Menglikirej' (op. cit. p. 3).

10. T. Czacki, 'O Tatarach', Dzieła, III, Poznań, 1845, p. 311.

11. A. Muchlinski, 'Zdanie sprawy', pp. 252-53.

12. The ancestors of the author of the Risāle appear to have come to the Grand Duchy at that time, as can be inferred from the following passage: 'Our arrival in this country is of relatively recent date. My father knew an old man who had come here with others, and who used to say that our families left their dwellings and came here, because they were weary of an unsettled life. It seems to me that our nobles are the descendants of the leading 
courtiers of the khans, who fought alongside them for the throne, but after the defeat of their masters were compelled to seek asylum in foreign lands' (A. Muchlinski, 'Zdanie sprawy', pp. 250-51).

13. A. Muchlinskij, 'Issledovanije o proischoždenii i sostojanii litovskich tatar', Godičnyj toržestvennyj akt v Imperatorskom Sanktpeterburgskom universitete byvšij 8 fevralja $1857 \mathrm{~g}$., St. Petersburg, 1857, pp. 131-132.

14. T. Czacki, op. cit., p. 311.

15. A. Muchlinskij, 'Issledovanije', p. 152.

16. Akty vilenskoj komissii dlja razbora drevnich aktov, Vol. 31: 'Akty o litovskich tatarach', Vilna, 1906, No. 92, pp. 139-140.

17. Akty, No. 181, p. 286.

18. The author of the Risāle, perhaps in answer to rebukes that the Lithuanian Tartars could not speak Turkish, writes: 'We have met in our travels Moslems, living even in the lands subject to the great Pādishāh, who knew little more than we; and if our people cannot speak Arabic or Turkish, they have on the other hand the knowledge of other tongues, for in our country everyone speaks the two languages which are there in common use' (A. Muchlinski, 'Zdanie sprawy', p. 260). The two languages referred to are, no doubt, Byelorussian and Polish.

It is interesting to refer to the testimony of another contemporary writer, Alexander Guagnini, an Italian who for many years lived in Poland and the Grand Duchy of Lithuania: 'Lingua eorum (i. e. Tartars) a polono idiomate tam longe abest, ut in Scythiam, ill in Sarmatiam commigrantes ranae seriphicae non iniuria dici queant. Qui tamen in Polonia et Lithuania et utroque Russia longe lateque dispersi sunt, plerumque hominum, quibuscum degunt, linguam addiscunt et callent' (Alexandri Guagninii, Rerum Polonicarum libri tres, II, Frankfurt, 1584, p. 412).

19. Akty, No. 46, p. 64.

20. Akty, No. 279, p. 451.

21. A. Muchlinski, 'Zdanie sprawy', p. 256.

22. On the legal position of the Tartars after 1588 see A. Muchlinskij, 'Issledovanije', p. 142 et seq.; also J. Talko-Hryncewicz, Muślimowie, czyli tak zwani Tatarzy litewssy, Cracow, 1924, p. 48 et seq.

23. Wł. Syrokomla, Wycieczki po Litwie $w$ promieniach od Wilna, II, Vilna, 1860 , p. 21 et seq.

24. For more detailed statistics cf. J. Talko-Hryncewicz, op. cit., p. 66 et seq.

25. Cf. A. Muchlinskij, 'Issledovanije', pp. 162-3. The author gives the number of mosques as 21, including some beyond the limits of the Byelorussian territory. According to Narbutt, in 1840 there were mosques in Vilna, Niamieža, Vaka (destroyed in 1812), Sorak-Tatary, Eryžy, Daŭbuciški, Krušyniany, Niekrašuncy, Navahrudak, Łoǔčycy, Asmałova, Lachavičy, Mir, Słonim, Studzienka, Bahoniki, Minsk, Vialikabolia, Vinižniupy (destroyed) and Jakovcy, the last one in Volhynia in the Ukraine. (Cf. T. Narbutt, Dzieje narodu litewskiego, VIII, Vilna, 1840, Appendix 2, p. 9 (note); cf. also J. I. Kraszewski, Wilno, III, 2, Vilna, 1841, p. 162, note 12). Nearly one hundred years later, in 1932, there were in western Byelorussia, then under Polish rule, sixteen mosques, namely in Vilna, Niamieža, Sorak-Tatary, Daŭbuciški, Miadziel, Navahrudak, Łoǔčycy, Słonim, Lachavičy, Muraǔščyna, Niekrašuncy, Asmałova, Mir, Krušyniany, Bahoniki and Vidzy (the last one in the course of construction). In addition to that there were two houses of prayer - in Dokšycy and Hłybokaje. (Cf. Rocznik Tatarski, I, Vilna, 1932, p. 323.)

26. M. Špilevskij, 'Putešestvije po Polessiju i belorusskomu kraju', Sovremennik, 7, St. Petersburg, 1853, Section 2, p. 23.

27. Zmitrok Biadula, 'U drymučych lasach', Zbor tvoraŭ, IV, Minsk, 1953, p. 456.

28. This is confirmed by the latest researches. M. Grinblat in his most recent work writes: 'The Tartars have borrowed from the Byelorussians several customs and works of folklore. The wedding customs of the Tartars hardly differ from the wedding ceremonies of the Byelorussians, with the exception of the ceremony of marriage itself, which is performed according to the Moslem rite' (M. Grinblat, Belorusy, Minsk, 1968, p. 171). 
29. Cf. Džemil Aleksandrovič, op. cit., p. 93.

30. Sciapan Aleksandrovič, 'Radzima maja - Kapyl', Pra čas i pra siabie, Minsk, 1966, pp. 7-8.

31. A. Muchlinskij, 'Issledovanije', p. 161.

32. M. Konopacki, 'Piśmiennictwo Tatarów polsko-litewskich w nauce polskiej i obcej', Przeglad orientalistyczny, 3, Warsaw, 1966, p. 202.

33. Catalogus librorum manuscriptorum qui in Biblioteca Senatoria civitatis Lipsiensis asservantur. Edidit Aemilius Guilelmus Robertus Nauman. Codices orientalium linguarum descripserunt Henricus Orthobius Fleischer et Franciscus Delitsch. Grimae MDCCCXXXVIII (1838).

Fleischer was responsible for the compilation of part 23 of :the catalogue, entitled Codices Arabici, Persici, Turcici (p. 329 et seq.). The description of the manuscript in question is found on pp. 450-51 under the number 179, and begins as follows: 'Codex arabicus, tataricus, polonicus, ab initio truncatus, 12-mo, foll. 147, char. neschi scriptus, quali Tatari utuntur, id est rustico et invetusto, quocum convenit charta non laevigata et in primis foliis foedissime inquinata. Foll. $1 \mathrm{r}-8 \mathrm{v}$ polonica utrinque trunca, literis arabicis scripta, quorum argumenta ex veteri testamento petita esse apparent. Quum is, qui me in his tenebris aliquantulum discutiendis humanissime adjuvit, Eques a Sokolnicki, juvenis ornatissimus apud nos Uteris studens, non omnia, quae ego titubante lingua legebam, intelligere et polonice rescribere posset, aliis et linguae polonicae et literarum arabicarum peritis illas plane dispellendas rellnquo.' The few short examples quoted by Fleischer are indeed in the Polish language, but with a marked Byelorussian influence. Antonovič in his recent work (see note 36) made a detailed study of the Leipzig manuscript (pp. 146-174) and in particular of the Byelorussian texts. According to him, texts in Polish, from which Fleischer quoted examples, are found only on the first 9 pages.

34. A. Muchlinskij, 'Issledovanije', pp. 174-182.

35. His main works are: in collaboration with $\mathrm{M}$. Tauerova (the Czech orientalist who worked out the transliteration of the Kitab): 'Adryvak z AlKitabu', Kryvič, 2 (8), Kaunas, 1924, pp. 46-51; 'Apaviadańnie z Al-Kitabu', Kryvič, 9 (1), Kaunas, 1925, pp. 69-79; alone: 'Biełaruskija muzułmanie i biełaruskaja litaratura arabskim piśmom', Hadavik biełaruskaha navukovaha tavarystva, 1, Vilna, 1933, pp. 111-141; 'Přispevki k dejinam beloruskeho jazyka na zakladě rukopisu Al-Kitab', Slavia, 12, Prague, 1933-34, pp. 357-390; 'Mova biełaruskaha (kryvickaha) rukapisu Al-Kitab', Kałośsie, Vilna, No. 4-1938, Nos 1, 2, 3-1939; Mova rukapisu Al-Kitab Kryvickaha muzeju Ivana Łuckieviča ŭ Vilni, New York, 1954.

36. A. Antonovič, Belorusskije teksty pisannyje arabskim pis'mom i ich graficoorfografičeskaja sistema, Vilna, 1968, p. 54.

37. Ju. Kračkovskij, 'Rukopis' Korana v Pskove', Izbrannyje sočinenija, I, Moscow-Leningrad, 1955, pp. 162-165; J. Karskij, Belorusy, III, 2, Petrograd, 1921, pp. 239-40; J. Szynkiewicz, 'O Kitabie', Rocznik tatarski, 1, Vilna, 1932, pp. 188-94; Chr. S. Stang, Die westrussische Kanzleisprache des Grossfürstentums Litauen, Oslo, 1935, pp. 125-32.

Other writers on the subject include Volski, Šlubski, Ćviatkoŭ and Woronowicz, but their works were not available to the authors of this article.

38. A. Zajączkowski, 'Так zwany chamaił tatarski ze zbioru rękopisów w Warszawie', Sprawozdania z czynności i posiedzeń Polskiej Akademii Umiejętności, LII, 4, Cracow, 1952, pp. 302-313.

39. M. Kanapacki, 'Pomniki arabska-biełaruskaj piśmiennaści', Niva, 20, Białystok, 1963, pp. 3, 5. Cf. also notes 2 and 32.

40. Cf. note 36; a review of this work appears in the JBS, II, 1, pp. 117-119.

41. The system of transliteration used in this article is essentially based on that of Antonovič (see his Belorusskije teksty, pp. 192-94), except that Latin characters have been used instead of the Cyrillic. An attempt has been made to keep the transliteration symbols as close as possible to the Byelorussian version of the Latin alphabet. The standard work in the English language to be consulted on all questions concerning the Byelorussian 
language (including the two alphabets) is R.G.A. de Bray, Guide to the Slavonic Languages, 2nd ed., London, 1969, pp. 129-190.

42. The letter "ž" is not recorded by Antonovič, but it definitely occurs in the copy of the Chamail of 1828, to which the authors of this article have been able to refer. (Cf. infra.)

43. The symbol "dź" seems to be more appropriate than "dz" used by Antonovič, as the consonant in question in the Byelorussian language is always soft.

44. Cf. A. Antonovič, op. cit, p. 341. The symbol "k'" surmounted by one dot is not recorded by Antonovič.

45. It should be stressed that the distinction between various letter-forms corresponding to a given vowel (or, for that matter, a consonant) is very relative, as they are all pronounced in the same way. The distinction is made for the sake of completeness and may be of interest for the philologist.

46. For the different forms of akannie a textbook on Byelorussian dialectology should be consulted, e. g. E. Blinava, Je. Miacielskaja, Biełaruskaja dyjalektałohija, Minsk, 1969, pp. 33-36.

47. Cf. Blinava, Miacielskaja, op. cit., p. 161.

48. It would not fall amiss to quote the opinion of the Norwegian slavist, Chr. S. Stang, who has made a special study of Middle Byelorussian: 'Das grosse linguistische Interesse der Kitabe besteht darin, dass diese von Mahomedanern mit arabischen Buchstaben geschriebene Texte von der kirchenslavischen Tradition ganz und gar unabhängig waren. Man findet hier das lebendige Weissrussisch jener Zeit; gewiss, es ist die Sprache gebildeter Kreise, denn diesen gehörten natürlich die Übersetzer und Abschreiber der Texte; aber trotzdem: die gesprochene Sprache, in einer vom Kirchenslavisch nicht beinflussten Orthographie' (Chr. S. Stang, op. cit., p. 126).

49. The Arabic and Turkish texts of the manuscripts have not been made the subject of any special study in the present article. It is necessary to note, however, that they contain many errors and corruptions and give the impression of having been copied by a person with imperfect knowledge, or none at all, of the languages concerned. There are in particular several words of Arabic, Turkish, Tartar and Persian origin in the Byelorussian texts. For the most part they are either personal names (e. g. Muśa Moses, Džebra'il - Gabriel etc.) or technical terms of Moslem theology (e. g. abdeśt - minor ritual ablution, du'a' - prayer, ferz - strict divine command etc.). They are given in the form used by the Byelorussian Tartars in the transliteration system adopted in this article. The same words in their usual form (in the conventional English transliteration) are written whenever necessary — with capital italic letters, e. g. DŽABR $\bar{A} ' \bar{I} L$.

50. The Arabic word HAMA'IL, as used by the Turks, means an amulet, inscribed on a piece of paper and worn by a person.

51. Many formulae on the amulets and medicinal writings are merely Koranic quotations. Thus the formula for aching eyes is Sūra 67, verse 4: 'Look again a second time: thy look shall be returned to thee driven back and dulled' (f. 189 v.). Sometimes there is no connection between the complaint and the remedy, as in the case of an aching chest, when the following formula is prescribed (Süra 17, verse 47): 'And when thou readest the Koran we place between thee and those who do not believe in the hereafter a covering veil' (f. 190 r.). Apart from the Koranic verses there are also special prayers and spells. The latter are often completely meaningless, as the spell to be written on three cloves of garlic: 'Asase besase šefas as as besas šefas asas besasa šefas śmasa' (f. 188 r.).

52. The text is nothing more than an enumeration of the so called Five Pillars of Islam: SHAHĀDA (profession of faith), SALĀT (ritual of daily prayer), $\bar{Z} A K \bar{A} T$ (alms-tax), HADJDJ (pilgrimage to Mecca) and SAWM (fast of Ramadan). The sixth tenet which is added to them is TAHARA (purification). These and several other matters contained in the Kitab and mentioned in this article (e. g. permitted and forbidden things) form part of the SHARI'A, the corpus of Moslem religious law. 


\section{APPENDIX}

\section{Selected Texts from the Writings of the Byelorussian Tartars.}

The following texts have been taken from the three manuscripts (the Tefsir of 1725, the Chamail of 1828 and the Kitab of the late 18th-19th century) described in the present article. All of them are written in the Byelorussian language, with the exception of No. 2 which is in Polish. The transcription is exact, except for the punctuation marks and the capital letters which are not found in the original writings, but which have been put into the transcribed texts in order to facilitate reading. The authors wish to thank the Keeper of Oriental Printed Books and Manuscripts of the British Museum for his kind permission to include photographic reproductions of two texts from the Chamail and three from the Kitab; and the Librarian of the Francis Skaryna Byelorussian Library in London for allowing the reproduction of two texts from the Tefsir.

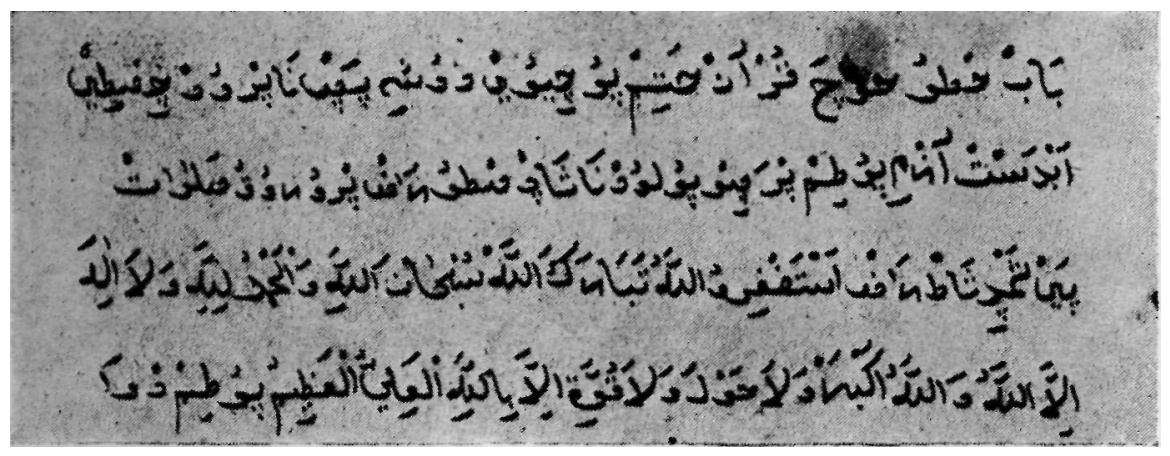

Trans cription.

Bab. Chtô chôče kur'ãn chet'im pôčivoj dûši pec, naprôd čistij

(2) ãbdeśt' ãźmi, pôtim preciv pôlûdna śadź, stô raz prôrôku selevet'

(3) pej, śemdźiśat raz... (the prayer in Arabic follows).

English translation.

Chapter. He who wishes to sing the complete Koran for a humble soul, first make the ablution for purification, then sit yourself facing south, sing a hundred times the praise of the Prophet, seventy times...

Notes.

Bab $(A r . B \bar{A} B)$ - chapter

chetim $(A r$. $)$ - complete

abdeśt' (Persian $\bar{A} B D A S T$ ) - minor ritual ablution

selevet' (Ar. SALAVATT) - praise, a short prayer in praise of the Prophet.

Translation of the prayer in Arabic (lines 3 and 4, after the word raz): 'Seek pardon of God, blessed be God, hallowed be God and praise to God, and there is no god but God, and God is greatest, and there is no power and strength save in God, the Exalted, the Mighty.' 
TEXT No. 2. THE TEFSIR OF 1725. SŪRA 1.

Transcription.

V îma Bôga laskavago mlôserdnegô. (2) Najlepša chva/la/ Bôgû, Panu i prôvizorôvi şvata, laskavemû, milôserdnemû, krûlôvî (3) dna sôndnegô. Tôbe slûže i klanamśe i ôd cebe pômôci žôndam. (4) Pravadź nas drôgą pravdźivą, drôgô ktûrą šli laskevci i mlôşnici, (5) nad nimi laska tvoja, ã tî ne činileś strôgôści nad nimi, ã ônî ne bilî blondnimi i źvedźônimi. Daj nam lak.

English translation.

In the name of the merciful and compassionate God. The highest praise belongs to God, the lord and provider of the world, the Merciful, the Compassionate, the king of the day of judgment. I serve you and worship you and seek your help. Guide us on the right path, the path followed by those who have found favour with you and love you, your grace is with them, and you did not deal with them with severity, and they did not err and were not led astray. Give us lak.

Notes.

The text is in the typical 'peripheral Polish' as it was spoken in Byelorussia. The influence of the Byelorussian language is evident (the hard "s" in the word "miloserdnemu"; unconscious akańnie in "pravadź"; "strogości" written with a " $\mathrm{t}$ "; the Polish word "błędnymi" written "blondnimi" in the way in which a Byelorussian would pronounce it; the word "źvedźonimi" which is typical of the Byelorussian language, but not of Polish). The word lak is unintelligible.

The whole translation is not literal and looks more like a paraphrase. 


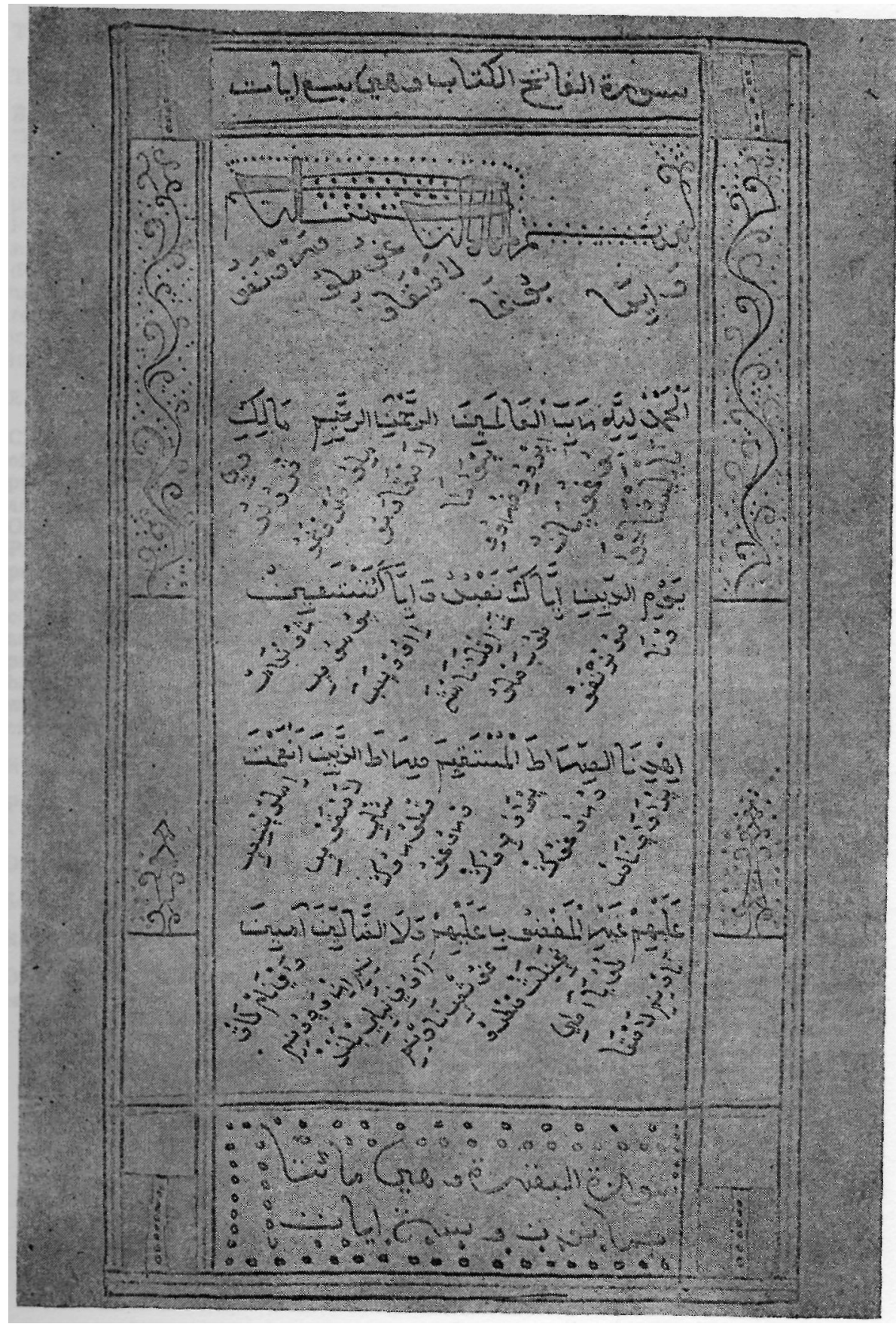


TEXT No. 3. THE CHAMAIL OF 1828. FOLIO 8 RECTO.

Transcription.

Bab. Šerchi. 'Elej śveti od (2) proroka jeho milośc movil: "A chto (3) bî hetûju du'û nad mahilaju (4) tri razi pev, nad tim mej*it'om Pan Boh (5) na pidźiśat hod mûk'i odlaic, ã ta (6) mû človeku Pan Boh ûśî hrechi (7) odpûści"... (the prayer in Arabic follows).

English translation.

Chapter. Commentary. Ali the holy one heard this from the gracious Prophet: 'Whosoever will sing this prayer three times over a grave, the Lord God will remit to that dead man fifty years of torment, and to that man the Lord God will grant forgiveness of all sins.'

Notes.

Šerchi (Ar. SHERH) - commentary, explanation

'Elej (ALI IBN $A B I \quad T \bar{A} L I B \quad$ (d. 661)) cousin and son-in-law of Muhammad, the last orthodox Caliph and first Imām of the Shī'ah. Held in great veneration among Muslims.

Du'a' (Ar.) - prayer.

Mej*it' (Ar. MEYIT) - the dead (sing.).

odlaic - a copyist's error; should be probably "addalic"

An approximate translation of the prayer in Arabic: 'This is the prayer: In the name of God the Merciful and
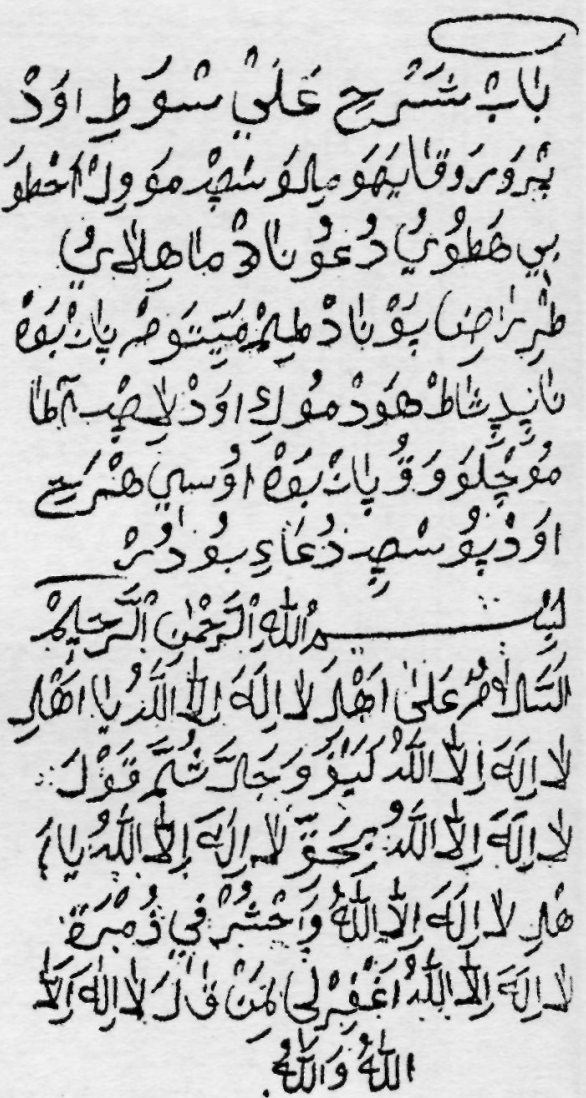

Compassionate: Peace be to the people of "There is no god but God".

O ye people of "There is no god but God", how are ye? Then saying "There is no god but God" by virtue of "There is no god but God". O ye people of "There is no god but God", may I be resurrected in the company of (those who say) "There is no god but God". Pardon me by virtue of him who said "There is no god but God".' 
TEXT No. 4. THE CHAMAIL OF 1828. FOLIO 232 RECTO.

Transcription.

Bab. Posel bož̂̌ jeho milo(2)śc rek: "Brace moj Džebra'ilu, heta (3) du'a'i važna jest, proša perepec, pa(4)sluchaju". Džebra'il jeho milośc pev. (5) prorok jeho milośc ûdźenčnij (6) bil, Panu Bohu mnoho chvali činil i (7) sechabejem pec dev. Sechabejove pelî (8) i napisali, dla hetaj du'a'i nabožnimi (9) stali i do žedanja prišli i rejśk'imi (10) zostali. Za du'a'elarem mnoho pec (11) i pri sobe naśic lekarstvo o dvuch śvatov jest.

\section{English translation.}

Chapter. The most gracious messenger of God said: 'Brother Gabriel, this prayer was important, sing it again and I shall listen.' The most gracious Gabriel sang, the most gracious Prophet was thankful, rendered much praise to the Lord God, and gave it to his companions to sing. The companions sang it and wrote it down, and thanks to this prayer they became pious, had their desires fulfilled and became famous. It is a cure in both worlds to sing it frequently and to carry it as an amulet.

\section{Notes.}

Posel boži - the messenger of God, i. e. Muhammad.

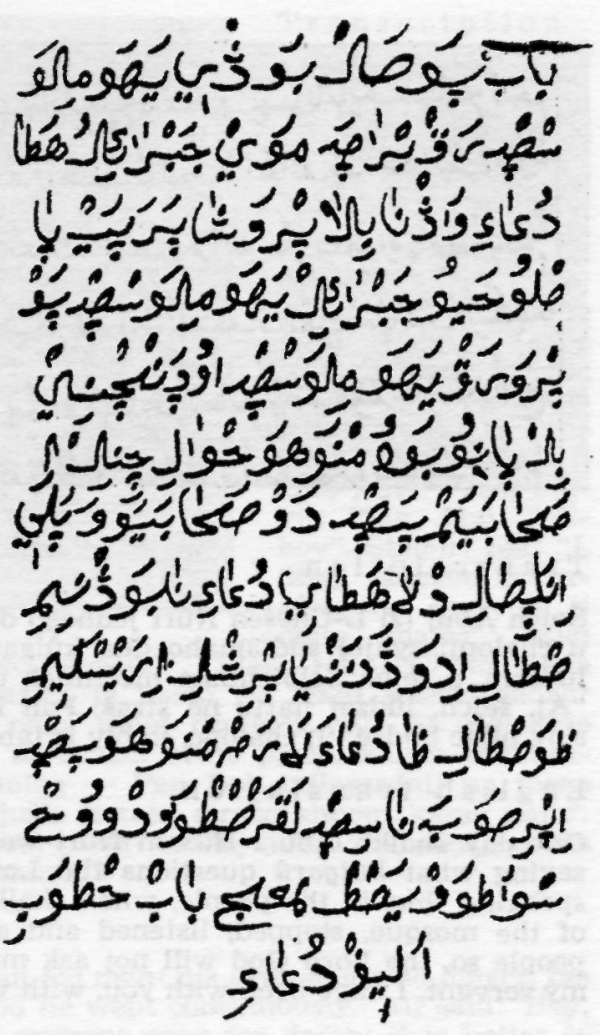

Džebra'il (Ar. DJABRĀ'IL) — Gabriel

Sechabejove, or sechabeji (Ar. $S A H \bar{A} B A$ ) - companions of Muhammad.

Rejśk'i, or rejś (Ar. RE' $\bar{I} S)$ - prominent, famous.

Du'a'elar - the Turkish plural form of an Arabic word, meaning prayers to be carried on a person, i. e. a talisman, amulet. 
TEXT No. 5. THE KITAB OF THE LATE 18th-19th CENTURY. FOLIO 13 RECTO.

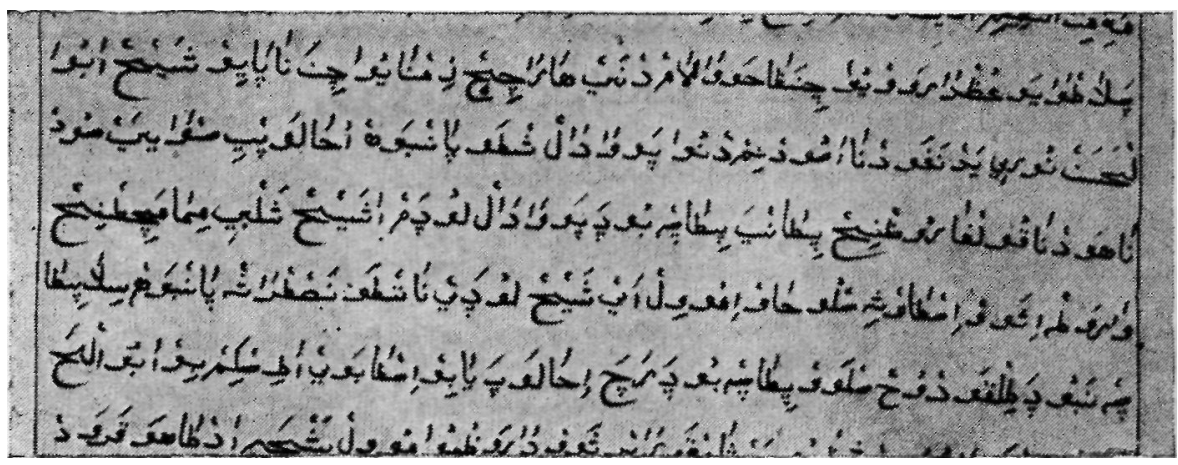

Transcription.

Šejch Abû| (2) L-Cheśen Nûri jednego dna a sûdnim dnû| povadal, što Pan Boh u chalopji svajej sûd(3)naho dna kûlgarû $\mathrm{z}$ nich pitanje pitac bûdźe. Povadal lûdźem, a šejch Šelbî mima mečitnich (4) varot išov i, stavši, slûchav i mûvil: "Aj, šejch, lûdźej nat'to ne straš, Pan Boh śila pita(5)c ne bûdźe, tilko dvuch slov pitac bûdźe: 'I, chalope, ja biv is taboju, a ti s k'im biv?'".

English translation.

One day shaikh Abū 1-Husain Nuri was teaching about the day of judgment, saying what kûlgarû questions the Lord God will ask his servants. He was speaking thus to the people, when shaikh Shebli who was passing by the door of the mosque, stopped, listened and said: 'Hey, shaikh, do not frighten the people so, the Lord God will not ask much, he will only say two words: "Hey, my servant, I have been with you, with whom have you been?'"

Notes.

This is one of the numerous anecdotes from the lives of the Moslem Süfis (mystics), which remind one very forcibly of similar anecdotes of the Christian Fathers of the Desert. The greatest collection of the former is the Memorials of the Saints (TADHKIRAT AL-AULIĀ) by the Persian poet Farīd al-Dīn 'Attār († c. 1230). Abu 1-Husain al-Nūrī and Al-Shiblī were two well known 9th century Sūfîs from Baghdad.

Kûlgarû - a word of uncertain meaning, probably the gerund form of the Tartar KULMAK - to ask in general, to demand.

I - a Turkish exclamation, meaning 'hey'. 
TEXT No. 6. THE KITAB OF THE LATE 18th-19th CENTURY. FOLIO 25 RECTO.

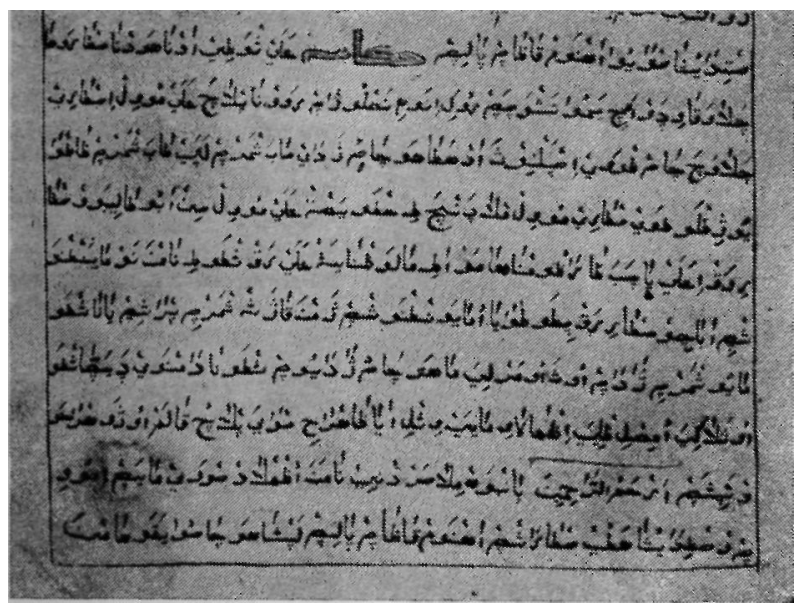

Trans cription.

Chik'ajet'. 'Elej śvetij adnaho dna staroha (2) čelaveka vidźev; oči jemû| he śvecec, rûk'i i nohi ne slûžac, rovna plače. 'Elej mûvil: "I, starij (3) čelaveče, čas tvoj ispelnivśe, ad hetaho času žedaj sabe śmerc, lepej tabe śmerc za tva(4)jo žitlo". Toj starij m-vil: "Mladźenče, ti chto jest?". "Elej m-vil: "Sin Abû Tal-bov". Sta(5)ri rek: "I, 'Elej, ja cebe za razûmnaha mev, a ti malo znaješ".' 'Elej rek: "Što ti na mne nevmajentno(6)ści abačiv?". Stari rek: "Ci to tvaja umajontnośc, že mne kažeš śmerci praśic? ja našto (7) majû śmerci žadac? ûśe ûmerlije maho času žadajûc, što nada mnoj dźejec*a, što (8) ûśelak'ije umisli zlije iz halavi majej višli, a ja za hrachi svaje plaču, kalem ûžo hracho(9)v ne pišec, - Archem al rrachimine - Pan Boh milaserdnij na mene uzhlad svoj majec i mûvi(10)c: 'Vstidajuśia hetuju straśc ahnom kazac palic'. Lepšaho časû| jekoha mne (Folio 25 verso) treba?". "Elej mûvil: "I, starij, prašu cebe, vibač mne, ja abmilivśe tak jak t'i mûviš".

English translation.

Story. 'Alī the holy one, saw one day an old man: his eyes shone no longer, his hands and legs refused to serve him, and he wept continuously. "Alī said: 'Hey, old man, your time is come, from this moment pray for death; it is better to die than to live in your estate.' The old man said: 'Who are you, young man?' And 'Alī said: 'I am the son of Abu Talib.' Then the old man said: 'Hey, 'Alī, I considered you to be a wise person, but you know little.' 'Alī said: 'What ignorance have you noticed in me?' The old man said: 'Is it your wisdom which tells me to pray for death? Why should I desire death? All the dead would wish to have my time and share my lot, since all manner of evil thoughts have left my head and I weep for my sins, and the pen no longer writes my sins; ARHAM AL-RĀHIMIN the merciful Lord God shows kindness towards me and says: "I am ashamed to condemn this old man to burn with fire." What better lot can I look for?' 'Alī said: 'Hey, old man, please forgive me, I was wrong, as you say.'

Notes.

Chik'ajet' (Ar. HIKĀYET) - story.

kalem (Ar. KALEM) - pen

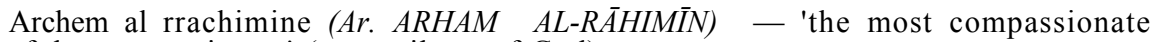
of the compassionate' (an attribute of God). 
TEXT No. 7. THE KITAB OF THE LATE 18th-19th CENTURY. FOLIO 115 RECTO.

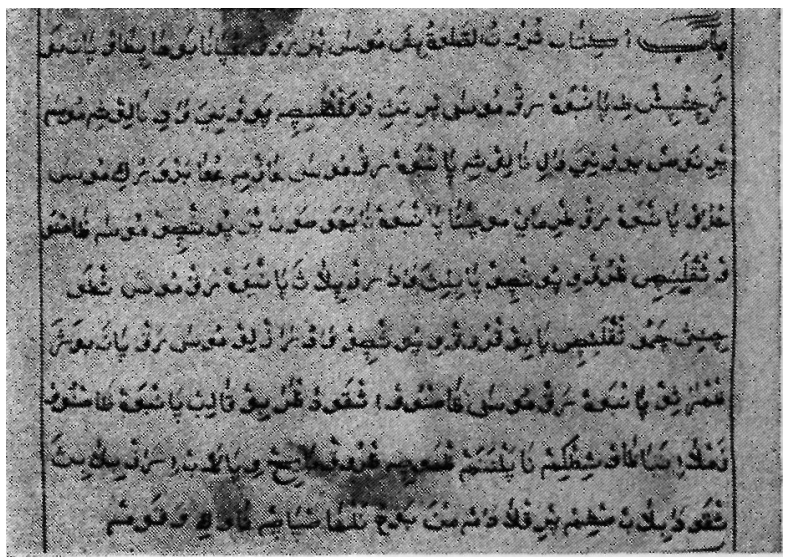

Transcription.

Bab. U k'it'abe Śurutu al-sselvet'u piše: Mûśâ prarok 'u Pana Boha pitav: "Pane Bo(2)že, či śpiš ti?". Pan Boh rek: "Mûśâ, prineśi dve šklenici povnije vadi". Nalivši, Mûśa (3) prinos povnije. Dali nalivši, Pan Boh rek: "Mûśâ, "aźmi "u 'abedve ruk'i". Mûśâ (4) 'uźav. Pan Boh rek: "Trimaj mocna". Pan Boh na jeho son prepûściv. Mûśâ zasnû(5)v, šklenici $\mathrm{z}$ ruk vipûściv - pabiliśe, vada reśpilaśe. Pan Boh rek: "Mûśâ, što (6) činiš, čemu šklenici pabiv, k rûk vipûściv, vadu raźliv?". Mûśâ rek: "Pane Bože, (7) zhrašiv". Pan Boh rek: "Mûśâ zasnûv i škodu zrabiv. Kali b Pan Boh zasnûv, (8) źemla i neba za všitk'im napelnenem $z$ moci $z$ rûk majich vipala b i raźbilibiśe, (9) škoda bila b. S tim prikladem mne Bohu nelha spac na vek'i vekom".

\section{English translation}

Chapter. It is written in the book SHURŪT EL-SALĀT. The prophet Moses asked of the Lord God: 'Lord God, do you sleep?' The Lord God said: 'Moses, bring me two glasses filled with water.' Moses brought them, having filled them. After filling them still more, the Lord God said: 'Moses, take them in both hands.' Moses took them. The Lord God said: 'Moses, hold them tightly.' The Lord God sent sleep on him. Moses fell asleep, and let the glasses fall from his hands: they broke and the water was spilled. The Lord God said: 'Moses, what have you done, why did you break the glasses letting them fall from your hands, and spill the water?' Moses said: 'Lord God, I have sinned.' The Lord God said: 'Moses fell asleep and did a mischief. If the Lord God fell asleep, then heaven and earth with all the fullness thereof would fall away from the might of my hands and would be broken, and a mischief would be done. This is why I, God, cannot sleep for ever and ever.'

Notes.

Śurut' al-sselvet' - or, in the usual English transcription, SHURŪT EL-SALĀT (Conditions of Prayer) - is the title of a book written in Arabic by the early 16th century Turkish writer KEMĀLPASHAZĀDE.

Mûśâ, also Mûśa - Moses

reźpilaśe - a mistake by the copyist; it should be probably 'reźlilaśe'. k ruk - a mistake by the copyist; it should be 'z ruk'. 